\title{
ERR $\beta$ signalling through FST and BCAS2 inhibits cellular proliferation in breast cancer cells
}

\author{
D Sengupta ${ }^{1,6}$, D K Bhargava ${ }^{1,6}$, A Dixit $^{2}$, B S Sahoo ${ }^{3}$, S Biswas ${ }^{4}$, G Biswas ${ }^{5}$ and S K Mishra*,1 \\ ${ }^{1}$ Cancer Biology Laboratory, Department of Gene Function and Regulation, Institute of Life Sciences (an Institute under the \\ Department of Biotechnology, Government of India), Nalco Square, Chandrasekharpur, Bhubaneswar, Odisha 751023, India; \\ ${ }^{2}$ Drug Design and Discovery, Department of Translational Research and Technology Development, Institute of Life Sciences \\ (an Institute under the Department of Biotechnology, Government of India), Nalco Square, Chandrasekharpur, Bhubaneswar, \\ Odisha 751023, India; ${ }^{3}$ Confocal Microscopic Facility, Institute of Life Sciences (an Institute under the Department of \\ Biotechnology, Government of India), Nalco Square, Chandrasekharpur, Bhubaneswar, Odisha 751023, India; ${ }^{4}$ Department \\ of Pathology, Sparsh Hospitals and Critical Care, A/407, Saheed Nagar, Bhubaneswar, Odisha 751007, India and ${ }^{5}$ Department of \\ Medical Oncology, Sparsh Hospitals and Critical Care, A/407, Saheed Nagar, Bhubaneswar, Odisha 751007, India
}

Background: The overexpression of oestrogen-related receptor- $\beta(E R R \beta)$ in breast cancer patients is correlated with improved prognosis and longer relapse-free survival, and the level of ERR $\beta$ mRNA is inversely correlated with the S-phase fraction of cells from breast cancer patients.

Methods: Chromatin immunoprecipitation (ChIP) cloning of ERR $\beta$ transcriptional targets and gel supershift assays identified breast cancer amplified sequence 2 (BCAS2) and Follistatin (FST) as two important downstream genes that help to regulate tumourigenesis. Confocal microscopy, co-immunoprecipitation (ColP), western blotting and quantitative real-time PCR confirmed the involvement of ERR $\beta$ in oestrogen signalling.

Results: Overexpressed ERR $\beta$ induced FST-mediated apoptosis in breast cancer cells, and E-cadherin expression was also enhanced through upregulation of FST. However, this anti-proliferative signalling function was challenged by ERR $\beta$-mediated BCAS2 upregulation, which inhibited FST transcription through the downregulation of $\beta$-catenin/TCF4 recruitment to the FST promoter. Interestingly, ERR $\beta$-mediated upregulation of BCAS2 downregulated the major G1-S transition marker cyclin D1, despite the predictable oncogenic properties of BCAS2.

Interpretation: Our study provides the first evidence that ERR $\beta$, which is a coregulator of ER $\alpha$ also acts as a potential tumoursuppressor molecule in breast cancer. Our current report also provides novel insights into the entire cascade of ERR $\beta$ signalling events, which may lead to BCAS2-mediated blockage of the G1/S transition and inhibition of the epithelial to mesenchymal transition through FST-mediated regulation of E-cadherin. Importantly, matrix metalloprotease 7, which is a classical mediator of metastasis and E-cadherin cleavage, was also restricted as a result of ERR $\beta$-mediated FST overexpression.

Oestrogen-related receptors (ERRs) are a group of nuclear receptors that are structurally and functionally related to oestrogen receptors (ERs) but do not bind oestrogen (Horard and Vanacker, 2003).
Diethylstilbestrol (DES), which acts as an ERR ligand (Tremblay et al, 2001), inhibits the growth of ER-positive and tamoxifenresistant ER-negative breast cancer cell lines (Lu et al, 2001).

*Correspondence: Dr SK Mishra; E-mail: sandipkmishra@hotmail.com

Part of this work has been presented in the Late Breaking (LB-27, Cell Growth Signalling Pathways) Category at the 103rd Annual Meeting of the American Association for Cancer Research 2012 (31 March-4 April); Chicago, IL, USA. Part of this work has been presented as an invited talk at the 3rd World Congress on Cancer Science and Therapy, held in San Francisco, CA, USA from 21st to 23rd October 2013.

${ }^{6}$ These authors contributed equally to this work.

Received 15 August 2013; revised 6 November 2013; accepted 13 January 2014;

published online 25 March 2014

(c) 2014 Cancer Research UK. All rights reserved 0007-0920/14

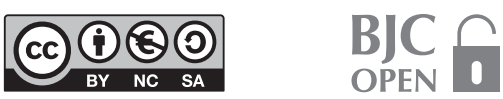


These actions suggest that ERR target genes should be investigated as potential therapeutic targets. Oestrogen-related receptor- $\beta$ regulates tumourigenesis differently from ERR $\alpha$ and ERR $\gamma$; whereas $\mathrm{ERR} \alpha$ and $\mathrm{ERR} \gamma$ expression levels are positively correlated with the development of steroid receptor-positive breast cancer (Riggins et al, 2010) and tamoxifen resistance (Riggins et al, 2008), $E R R \beta$ mRNA expression levels are inversely correlated with the $S$-phase fraction (Ariazi et al, 2002) of breast tumour cells, which suggests that cellular proliferation is inhibited by $\operatorname{ERR} \beta$.

Oestrogen-related receptor- $\beta$, like many other nuclear receptors, can be divided into five structural domains, including the $\mathrm{A} / \mathrm{B}$ (activation function-1 (AF-1) or ligand-independent domain), $\mathrm{C}$ (DNA-binding domain), D (hinge region containing nuclear localisation signal), E (ligand-binding domain (LBD) or AF-2) and $\mathrm{F}$ domains (coregulator functions, dimerisation and localisation) (Nilsson et al, 2001). The $\mathrm{C}$ domain of $\operatorname{ERR} \beta$ shares $\sim 73 \%$ homology with $\mathrm{ER} \alpha$ (Zhou et al, 2006), and hence, as expected, $\mathrm{ERR} \beta$ and $\mathrm{ER} \alpha$ have common transcriptional targets, such as $p S 2$ (Lu et al, 2001), which is an important marker for cancer.

Oestrogen-related receptor- $\beta$ binds as a homodimer to at least two types of response elements (Horard and Vanacker, 2003), including full oestrogen response elements (classical EREs: AGGTCAnnnTGACCT) and the SF-1 response element (SFRE/ ERRE: TnAAGGTCA), which is an extended half ERE site. Oestrogen-related receptor- $\beta$ also heterodimerises with other ERRs (Horard et al, 2004), and the $\mathrm{F}$ domain of $\operatorname{ERR} \beta$ may heterodimerise with $\mathrm{ER} \alpha$ to modulate $\mathrm{ER} \alpha$-mediated ERE-dependent gene transactivation (Bombail et al, 2010).

Oestrogen-related receptor- $\beta$ precursor mRNA comprises 12 exons (Zhou et al, 2006), and it is spliced into 3 isoforms: $E R R \beta 2$ (long form), ERR $\beta 2 \triangle 10$ (10th exon deleted) and ERR $\beta S$ (short form with the $\mathrm{F}$ domain deleted). Only the short form of $\operatorname{ERR} \beta$ is expressed in breast tissue (Zhou et al, 2006), and these isoforms also differ in tissue specificity, intracellular localisation and the modulation of ERE-dependent $\mathrm{ER} \alpha$ transcriptional activity (Yu et al, 2008).

Oestrogen-related receptor- $\beta$ may have anti-proliferative properties (Ariazi et al, 2002) in breast cancer cells, and this receptor may activate the $p 21^{\mathrm{WAF} / \mathrm{CIP} 1}$ promoter (Yu et al, 2008) in prostate cancer cells, which is a universal inhibitor of cyclindependent kinases (CDKs; Xiong et al, 1993). P21 expression decreases with oestrogen treatment and the development of antioestrogen resistance (Mukherjee and Conrad, 2005), which supports the importance of $\operatorname{ERR} \beta$ as a therapeutic agent in breast cancer.

Limited studies have reported the role of $\operatorname{ERR} \beta$ in breast cancer cells (Lu et al, 2001; Ariazi et al, 2002; Bombail et al, 2010). One report found $E R R \beta$ to act as a proliferative gene (Lu et al, 2001), whereas a conflicting study raised the possibility of $\operatorname{ERR} \beta$ acting as an anti-proliferative factor (Ariazi et al, 2002). Therefore, our study sought to unravel the functional significance of $\operatorname{ERR} \beta$ in breast cancer cells and the deregulation of oestrogen signalling, as well as several key issues associated with breast tumourigenesis.

Our primary goal was to explore the association of $\operatorname{ERR} \beta$ expression with the proliferative or anti-proliferative properties of the cells. Therefore, we performed chromatin immunoprecipitation (ChIP) cloning (Mishra et al, 2001) of ERR $\beta$ transcriptional targets and shortlisted two genes, breast cancer amplified sequence 2 (BCAS2) and Follistatin (FST), on the basis of their opposing roles in proliferation. Subsequently, we identified the bona fide binding sites (i.e., the ERREs in the promoters of the BCAS2 and FST genes) by confirming the binding of $\operatorname{ERR} \beta$ to the identified sites. However, oestrogen signalling may also regulate BCAS2 and FST, which we demonstrated by showing that $\mathrm{ER} \alpha$ was recruited to the relevant ERREs. We also investigated the effect of ERs and ERR $\beta$ interactions on BCAS2 and FST, and we successfully revealed the relationship between BCAS2 and FST signalling events. Moreover, Kaplan-Meier (KM) plotter survival analyses supported our conclusions (Gyorffy et al, 2010). Besides, our results suggest that regulation of the G1-S transition by $\beta$-catenin, of the epithelial to mesenchymal transition (EMT) by E-cadherin and of the induction of apoptosis in breast cancer cells is mediated through $\operatorname{ERR} \beta$ transregulation of BCAS2 and FST.

\section{MATERIALS AND METHODS}

Cell culture and treatments. The human breast carcinoma cell lines MCF-7 (ATCC HTB-22), MDA MB 231(ATCC HTB-26), ZR-75-1 (ATCC CRL-1500) and T47D (HTB-133) were purchased from National Centre for Cell Science, Pune, India. These cells were routinely subcultured in Dulbecco's modified Eagle's medium (DMEM with $4.5 \mathrm{gl}^{-1}$ glucose, L-glutamine, sodium pyruvate, $3.7 \mathrm{gl}^{-1}$ sodium bicarbonate; from Pan Biotech, $\mathrm{GmbH}$, Aidenbach, Germany) containing 10\% heat-inactivated foetal bovine serum (South American Origin, Aidenbach, Germany) and antibiotics (penicillin/streptomycin) in a humidified atmosphere of $5 \% \mathrm{CO}_{2}$ at $37^{\circ} \mathrm{C}$.

Cells were maintained in charcoal-stripped phenol red-free DMEM for at least 3 days before treatment. The cells were treated with $10 \mathrm{~nm}$ oestrogen (Sigma, St Louis, MO, USA), $10 \mathrm{~nm}$ DES (Sigma), $1 \mu \mathrm{M}$ ICI182780 (Sigma) and $1 \mu \mathrm{M}$ tamoxifen (Sigma) for the time periods indicated in the figures and text and processed for the extraction of whole-cell lysates for western blot.

Western blotting. Whole-cell lysates were prepared using RIPA buffer. Approximately $70 \mu \mathrm{g}$ of cell lysates were loaded per lane. Transfer was performed onto PVDF membranes (Millipore, Temecula, CA, USA) overnight at $40 \mathrm{~V}$. The transfer efficiency was monitored using Ponceau S staining, and the membranes were incubated in primary and secondary antibody according to the instructions on the antibody datasheets after blocking with non-fat dry milk (Santa Cruz Biotechnology, Inc., Santa Cruz, CA, USA). Membrane washes were performed in TBS-T, and the X-ray film (Kodak, Rochester, NY, USA) was developed after luminol (GE Healthcare, Buckinghamshire, UK) incubation over the membrane. Oestrogen-related receptor- $\beta$ was developed, the membrane was stripped with stripping buffer (Pierce, Brebierers, France) and incubated with $\alpha$-tubulin (Sigma)/FST (Santa Cruz Biotechnology, Inc.)/BCAS2 (Eurogentec, Seraing, Belgium)/ERR $\beta$ (Santa Cruz Biotechnology, Inc.)/ER $\beta$ (Epitomics, Burlingame, CA, USA) and ER $\alpha$ (Bethyl Laboratories, Inc., Montgomery, TX, USA)/ E-cadherin (Epitomics)/ $\beta$-catenin (Epitomics)/cyclin D1 (Santa Cruz Biotechnology, Inc.)/cleaved PARP (Cell Signaling Technology, Beverly, MA, USA)/GAPDH (Santa Cruz Biotechnology, Inc.) antibodies and developed following similar procedures.

ChIP assay/cloning. MCF-7 cells were grown to $90 \%$ confluence in DMEM containing 10\% FBS. Cells were crosslinked with $1 \%$ (v/v) formaldehyde, and crosslinking was stopped with $0.125 \mathrm{M}$ glycine. Immunoprecipitation was performed as per Farnham's ChIP protocol. The primers used in the $\mathrm{ERR} \beta / \mathrm{ER} \alpha \mathrm{ChIP}$ are mentioned in the Table 3.

For ChIP cloning, purified ChIP elutes were ligated to a pGEMT-Easy TA vector from Promega (Madison, WI, USA) and transformed in E. coli strain JM109. Plasmids were isolated from individual colonies and digested with EcoR1/NotI for the presence of inserts.

Plasmid and transfections. MCF-7 and MDA-MB 231 cells were subcultured 1 day before transfection to $70 \%$ confluence. Transfection was performed using GENECellin HTC (Larova, Jena, Germany) according to the manufacturer's protocol.

Real-time PCR. Total RNA was isolated from MCF-7 cells using the Trizol method. A total of $2 \mu \mathrm{g}$ of total RNA was used for cDNA preparation using a first-strand cDNA synthesis kit 
(Invitrogen, Carlsbad, CA, USA). This cDNA was used as the template for real-time PCR.

Flow cytometric analyses. Cells were stained using a PE Annexin V Apoptosis Detection Kit (BD Pharmingen, San Diego, CA, USA) according to the manufacturer's protocol, and immediate acquisition was performed with a BD FACS Calibur using CellQuest Pro Software (San Jose, CA, USA). Using single positive controls in the setup mode, fluorescence compensation was adjusted to subtract the percentage of negative cells from positive cells and avoid spectral overlap. Approximately 10000 cells were acquired and analysed using an FL3 filter for 7-AAD-positive cells and an FL2 filter for PE-annexin V-positive cells.

Confocal microscopy. Samples containing ER $\alpha$-CFP, ER $\beta$-CFP, ERR $\beta$-YFP and propidium iodide (PI)/DRAQ5 were captured with a confocal microscope (Leica TCS SP5; Leica Microsystems CMS GmBH, Mannheim, Germany) using LAS AF (Leica Application Suite Advanced Fluorescence) 1.8.1 build 1390 software under an HCX PL APO lambda blue oil-immersion objective (63.0X/ N.A.1.40) with a confocal pinhole set at Airy 1 and a resolution of 8 bits. CFP and YFP were excited at $458 \mathrm{~nm}, 514 \mathrm{~nm}$ (Argon laser 30\% and AOTF 458 (40\%) and YFP (35\%)) sequentially with emission (CFP: $462-510 \mathrm{~nm}$, YFP: $520-580 \mathrm{~nm}$, DRAQ5: $650-$ $700 \mathrm{~nm}$; PI: $\sim 617 \mathrm{~nm}$ ) and a PMT gain of 1175 and $950 \mathrm{~V}$, respectively. The offset was adjusted for a maximum range of fluorescence from 0 to 255 (50\% green pixel). Propidium iodide was excited as follows: DPSS $561 \mathrm{~nm}$ laser, for DRAQ5- $633 \mathrm{~nm}$ laser (AOTF: 40\%). Images were captured sequentially with CFP and YFP (emission at 600-630 $\mathrm{nm}$ and PMT gain $1050 \mathrm{~V}$ ).

RNA interference. Breast cancer amplified sequence 2, FST and control siRNA against laminin were purchased from Eurogentec. $\beta$-Catenin and control shRNA were purchased from Addgene Cells (Cambridge, MA, USA) and transfected with siRNAs using the ICAFectin 442 (Eurogentec). Cells were subcultured 1 day before transfection to reach $60-70 \%$ confluency on the day of transfection. The growth medium was removed $30 \mathrm{~min}$ before transfection, and $500 \mu \mathrm{l}$ fresh medium without serum was added. siRNA $(100 \mathrm{~nm})$ was used for transfection. Transfection was performed according to the manufacturer's protocol. Cells were harvested $24 \mathrm{~h}$ post-transfection.

Co-immunoprecipitation. Cells were washed with PBS $\mathrm{pH} 7.4$ twice and lysed with NP40 buffer (50 mm Tris-Cl pH 8.0, $150 \mathrm{~mm}$ $\mathrm{NaCl}, 1 \% \mathrm{NP} 40$ ). Lysates were precleared by the addition of $50 \mu \mathrm{l}$ of agarose beads for $30 \mathrm{~min}$. Total protein $(600 \mu \mathrm{g})$ and $4 \mu \mathrm{g}$ of antibody were used for each IP and rotated overnight in $4{ }^{\circ} \mathrm{C}$. Beads $(30 \mu \mathrm{g})$ were added to each IP and rotated for $2 \mathrm{~h}$, followed by centrifugation at 1000 r.p.m. for $3 \mathrm{~min}$. Supernatants were removed, and pellets were washed four times with NP40 buffer. Complexes were eluted in SDS lysis buffer.

EMSA. MCF-7 cells were lysed using cell lysis buffer $(20 \mathrm{~mm}$ HEPES pH 7.9, 20\% glycerol, 0.1\% Triton X 100, $10 \mathrm{~mm} \mathrm{NaCl}, 1.5 \mathrm{~mm}$ $\mathrm{MgCl}_{2}, 1 \mathrm{~mm}$ EGTA, $1 \mathrm{~mm}$ EDTA and protease inhibitor cocktail), and nuclear lysates were prepared using $20 \mathrm{~mm}$ HEPES ( $\mathrm{pH} 7.9,20 \%$ glycerol, $420 \mathrm{~mm} \mathrm{NaCl}, 10 \mathrm{~mm} \mathrm{MgCl}_{2}$, 1 mм EGTA, 1 mm EDTA and protease inhibitor cocktail). Oligos were labelled using $\gamma \mathrm{dATP}$. The EMSA reaction was performed using $5 \mathrm{X}$ binding buffer (20\% glycerol, $100 \mathrm{~mm}$ HEPES pH 7.9, $300 \mathrm{~mm} \mathrm{KCl,} 25 \mathrm{~mm} \mathrm{MgCl}_{2}, 4 \mathrm{~mm}$ EDTA), $3 \mu \mathrm{g}$ BSA, $1 \mu \mathrm{g}$ poly dIdC at room temperature. The reaction was run on $6 \%$ nondenaturing PAGE gels.

KM plotter analyses. Relapse-free survival information was taken into account from GEO (Affymetrix HGU133A and HGU133 + 2 microarrays, Santa Clara, CA, USA), EGA and TCGA for the drawing of KM plots. Patient samples were divided into two groups by computing the median of the expression level of the proposed biomarker and selecting the best cut-off threshold using the percentiles between upper and lower quartiles to analyse the prognostic value of a particular gene. Optimal probe sets were selected for each gene using a scoring method established to assess specificity, coverage and degradation resistance. The two-patient cohorts of 2896 clinical samples were compared using KM survival plots, and the hazard ratio with 95\% confidence intervals and logrank $P$-values were calculated. Affymetrix gene ID: 207726_at, 203053_at and 204948_s_at were used to plot the survival curves of $\operatorname{ERR} \beta, \overline{B C A S} 2$ and $\mathrm{FST}$, respectively.

3D structural modelling. The model of $\operatorname{ERR} \beta$ homo sapiens protein (508AA) was built using I-TASSER, which generates 3D structural models using multiple threading alignments and iterative structural assembly simulations (Roy et al, 2010). The docking $(\operatorname{ERR} \beta$ with $\operatorname{ER} \alpha$ and $\operatorname{ERR} \beta$ with $\operatorname{ER} \beta$ ) was performed using ZDOCK (Mintseris et al, 2007; Pierce et al, 2011), which uses a fast Fourier transformation to perform a $3 \mathrm{D}$ search of the spatial degrees of freedom between two molecules. The Z-dock can generate a $3 \mathrm{D}$ structural model of the interaction between two macromolecules. This study used docking without constraints on the protein structure. The best model was selected based on the Z-dock score and similarity with related protein complexes.

\section{RESULTS}

$\operatorname{ERR} \beta$ overexpression is associated with apoptotic induction and improved prognosis in breast cancer cell lines and patients. No reports of relative $\operatorname{ERR} \beta$ expression in breast cancer cell lines have been published. We therefore performed western blots to investigate $\operatorname{ERR} \beta$ expression in breast cancer cell lines. Oestrogenrelated receptor- $\beta$ was overexpressed in immortalised normal MCF10A cells compared with ER-positive MCF-7 and T47D cells and ER-negative SKBR3, MDA MB 231 and MDA MB 453 cells (Figures 1A-I and II). We next analysed the morphological changes induced following $\operatorname{ERR} \beta$ long-form $(\operatorname{ERR} \beta \mathrm{L})$ overexpression in the human breast cancer cell line MCF-7, based on the abovementioned results and the reduced expression of $\operatorname{ERR} \beta$ in cancer cell lines compared with immortalised cell lines (Yu et al, 2008). MCF-7 cells in which ERR $\beta \mathrm{L}$ was overexpressed showed distinct nuclear fragmentation (Figure 1B) according to PI staining, which is a morphological feature of apoptotic cells (Dini et al, 1996). Step-wise events associated with apoptosis (Wade et al, 2001), such as non-protruding crescents indicative of chromatin condensation and the formation of vessels containing condensed chromatin in the periphery of the nucleus, were also observed. We then overexpressed ERR $\beta$ in MCF-7 cells and performed an annexin V-PE apoptosis detection assay. In all $84.53 \%$ of the gated viable cells exhibited annexin-positive and 7AAD-negative staining; this result was indicative of early apoptotic events and was in contrast to the vector control, which demonstrated $2.32 \%$ positive staining (Figures 1C-I and II).

Oestrogen-related receptor- $\beta$ overexpression in breast cancer cell lines was reduced compared with the immortalised normal breast cell line MCF-10A. Therefore, we investigated whether this reduced expression was associated with the development of malignancy. We isolated protein lysates from one benign (control) and two malignant tumour samples from breast tumour patients and performed western blotting. The benign sample was used as the control because normal breast tissue was not available, and the results indicated that $\operatorname{ERR} \beta$ expression was reduced in the malignant samples (Figure 1D). This in vivo study suggested that decreased $\operatorname{ERR} \beta$ expression was physiologically relevant in the development of malignancy.

We next performed KM plotter analysis $(n=2978)$ to obtain statistically sound data for the association of $\operatorname{ERR} \beta$ with breast cancer patient survival. Kaplan-Meier plotter analyses 
A

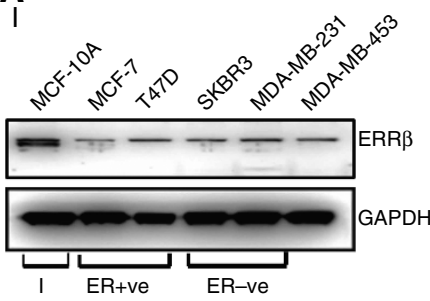

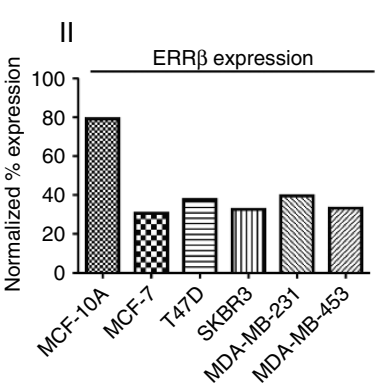

C

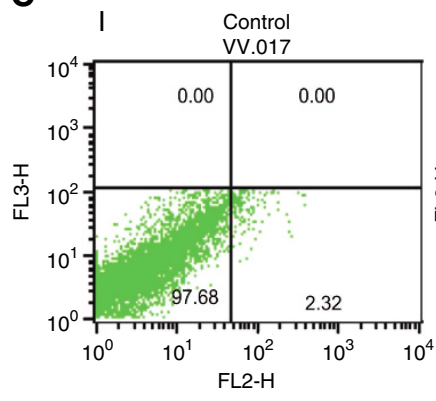

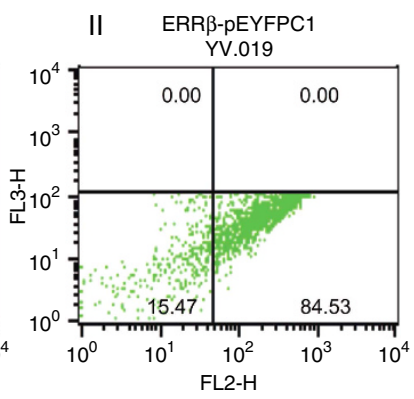

E
B

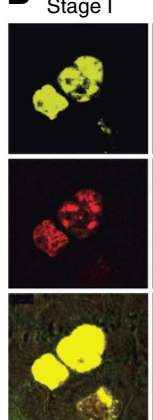

Stage II

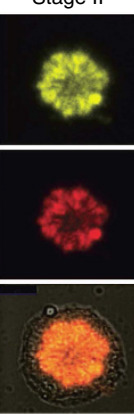

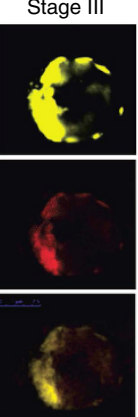

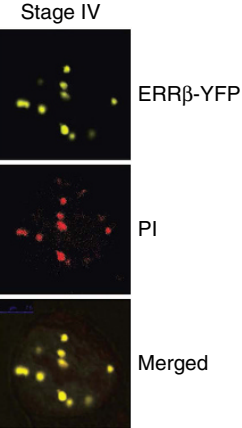

D
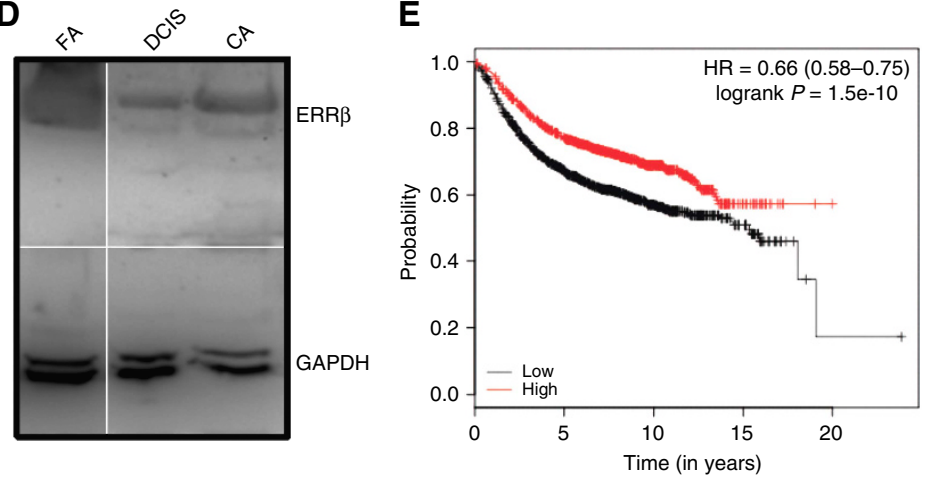

Figure 1. ERR $\beta$ as an anti-proliferative molecule. (A-I) Western blot showing ERR $\beta$ comparative expression in different breast cell lines. (II) Densitometric analyses denoting higher ERR $\beta$ expression in immortalised (I) breast cells (MCF-10A) compared to breast cancer cell lines. The histogram of \% protein expression was calculated by normalising with the corresponding control. (B) Different stages apoptotic nuclear fragmentation as shown by confocal microscopy in MCF-7 cells. The emission maxima were $535 \mathrm{~nm}$ for ERR-YFP and $617 \mathrm{~nm}$ for PI. Propidium iodide staining was performed to monitor nuclear morphology post-RNase treatment. (C-I and II) Flow cytometric analyses showing apoptosis induction in ERR $\beta$-pEYFPC1-overexpressing (II) MCF-7 cells in comparison with the vector control (I). Detection of apoptotic cells was performed using the FL2 channel of BD FACS Calibur and annexin V-PE as an apoptotic indicator. The dead cell population was gated out using 7-AAD as a vital stain and FL3 as the detection channel. (D) Western blot for human tumour samples showing reduced ERR $\beta$ expression in malignant tumours (DCIS and CA) compared with a benign tumour (FA). (E) Kaplan-Meier plotter analysis (for statistical significance) showing that high ERR $\beta$ expression was associated with better prognosis and longer relapse-free survival in breast cancer patients. Abbreviations: $\mathrm{CA}=$ carcinoma; DCIS = ductal carcinoma in situ; FA = fibroadenoma.

(Gyorffy et al, 2010) showed (Figure 1E) that high $\operatorname{ERR} \beta$ expression was associated with improved prognosis and higher relapse-free survival rates compared with low $\operatorname{ERR} \beta$ expression, which supports the anti-proliferative nature of $\operatorname{ERR} \beta$.

FST and BCAS2 are two important transcriptional targets of $\operatorname{ERR} \beta$ that bind to $\sim 6-\mathrm{kb}$ and $\sim 8$-kb upstream of the BCAS2 and FST transcription start sites (TSSs), respectively, and upregulate their transcription. We performed ChIP cloning in MCF-7 breast carcinoma cells to identify the transcriptional targets of $\operatorname{ERR} \beta$ (Supplementary Figures 1A, B, C, D, E and F). TA cloning of $\operatorname{ERR} \beta$ target sequences isolated hundreds of colonies, which were sequenced to identify the important targets. The primers used for sequencing are listed in Table 1.

Nucleotide BLAST searches were performed in NCBI against human genomic DNA sequences, and probable target promoters were shortlisted (data not shown) based on the total score, $\Delta \mathrm{E}$ value, query coverage and features flanking part of the subject sequence.

Chromatin immunoprecipitation cloning identified BCAS2 and FST as significant target genes (Table I in Figure 2) of ERR $\beta$. Breast cancer amplified sequence 2 is a co-activator of $\mathrm{ER} \alpha$ (Qi et al, 2005) and a negative regulator of p53 (Kuo et al, 2009). Follistatin enhances the ability of R30C breast carcinoma cells to induce sub-G1 populations (Krneta et al, 2006) and inhibits multi-organ metastasis of small cell lung carcinoma in natural killer cell-deprived SCID mice (Talmadge, 2008).

The screening of up to $10-\mathrm{kb}$ upstream from the BCAS2 and FST TSSs revealed the presence of ERRE sites at -6077 to -6086

$\mid$\begin{tabular}{l|l|}
\hline \multicolumn{2}{|l|}{ Table 1. Primer used for sequencing } \\
\hline Primer name & Sequence $\left(5^{\prime}-\mathbf{3}^{\prime}\right)$ \\
\hline T7 forward primer & TAATACGACTCACTATAGGG \\
\hline
\end{tabular}

upstream from the BCAS2 TSS (Supplementary Figure 1G) and -8678 to -8687 (distal site) and -5132 to -5141 (proximal site) upstream from the FST TSS (Supplementary Figure 1H). No fulllength ERE was found up to $10-\mathrm{kb}$ upstream from either TSS.

Electrophoretic mobility shift assays (EMSAs) were performed to confirm the specific recruitment of ERR $\beta$ to ERREs upstream of the BCAS2 and FST promoters (Figures 2A and 3A). Breast cancer amplified sequence 2 ERRE and distal ERRE (ERRE 2) of FST showed specific binding patterns (Vanacker et al, 1999) related to the co-recruitment of $\operatorname{ER} \alpha$ and $\operatorname{ERR} \beta$. Supershift assays confirmed the in vitro $\operatorname{ERR} \beta$ binding to the FST ERRE2. The BCAS2 ERRE showed competition in the $\mathrm{ER} \alpha$ band, which was less in the $\operatorname{ERR} \beta$ band; however supershift for $\operatorname{ERR} \beta$ was observed. The oligos used in the EMSA are listed in Table 2.

We next investigated the in vivo $\operatorname{ERR} \beta$ binding to the BCAS2 ERRE and FST ERRE2 under vehicle treatment and 24-h oestrogen treatment using the ChIP assay (Figures $2 \mathrm{~B}$ and $3 \mathrm{~B}$ ). Oestrogenrelated receptor- $\beta$ binding to both ERREs was compromised under 24 -h oestrogen treatment, which indicates that the oestrogendependent conformational change in $\operatorname{ERR} \beta$ loosened $\operatorname{ERR} \beta$ from the respective ERREs. The primers used in the ChIP assays are listed in Table 3. 


Table I
\begin{tabular}{|l|l|l|l|l|}
\hline S.no. & Accession no. & Reference gene name & No. of hits & Function \\
\hline 1 & NT 007592.15 & $\begin{array}{l}\text { Breast cancer amplified } \\
\text { sequence 2 }\end{array}$ & 4 times & Coactivator of ER $\alpha$ and negative regulator of p53 \\
\hline 2 & NM_013409.1 & Follistatin & 2 times & FSH inhibitor, inhibitor of multi-organ metastasis \\
\hline
\end{tabular}

A

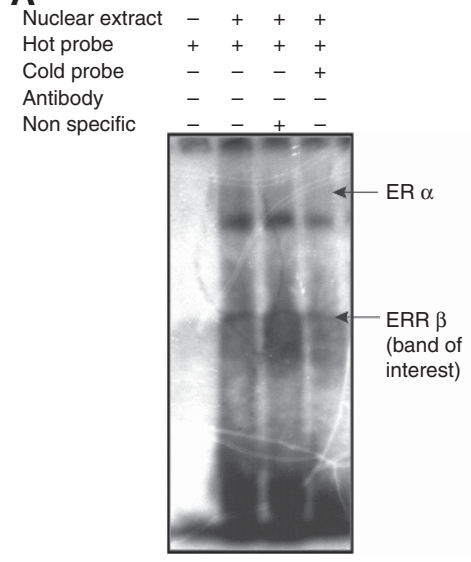

C

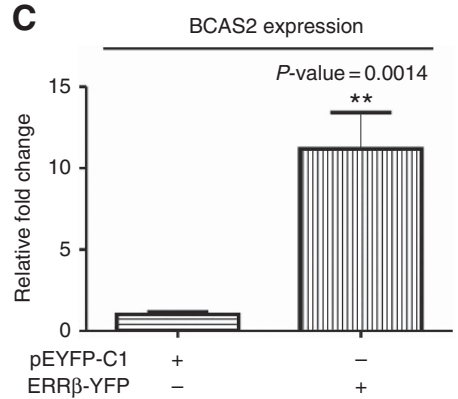

B

$-+++$

$++++$

$-++$

$-+$

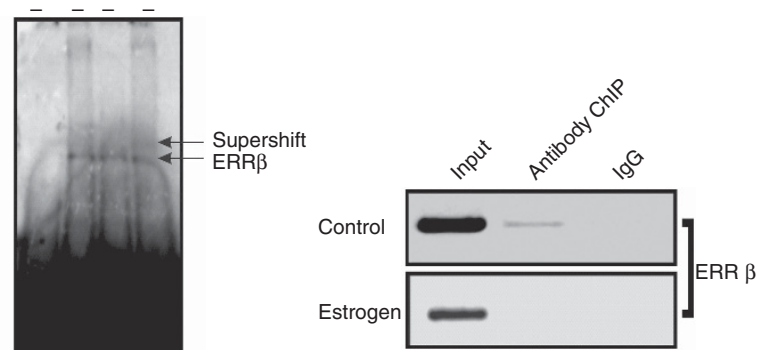

D

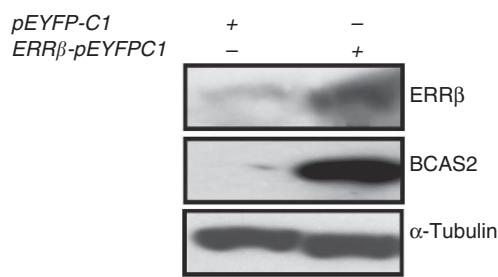

Figure 2. BCAS2 as a transcriptional target of ERR $\beta$. (A) Electrophoretic mobility shift assay showing the in vitro binding of transcription factors in the ERRE of BCAS2 promoters and supershift confirming ERR $\beta$ binding. (B) Chromatin immunoprecipitation confirming the in vivo ERR $\beta$ binding to BCAS2 ERRE in MCF-7 cells. (C) Real-time PCR data showing the upregulation of BCAS2 transcripts under ERR $\beta$ overexpression. Asterisks ( ${ }^{*}$ ) indicates significance ( $t$-test compared with control; $P<0.05$ ). (D) Western blot confirming the upregulation of BCAS2 protein expression under ERR $\beta$ overexpression. Abbreviation: ERRE = oestrogen related receptor response element.

We then investigated the effect of overexpressed $\operatorname{ERR} \beta$ on $B C A S 2$ and FST transcription using real-time PCR. Overexpressed ERR $\beta$ upregulated BCAS2 and FST mRNA levels (Figures 2C and 3C). The primers used for real-time PCR are listed in Table 4. Real-time figures of ERR $\beta$ transfection are shown in Figure 2A. The upregulation of BCAS2 and FST proteins following ERR $\beta$ overexpression was confirmed using western blotting (Figures 2D and 3D).

Involvement of ERs in ERR $\beta$-mediated BCAS2 and FST signalling. The western blotting, real-time PCR and ChIP results showed that the $\operatorname{ERR} \beta$ transcriptional targets BCAS2 and FST were also regulated by $\operatorname{ER} \alpha$ and that the $\operatorname{ERR} \beta$ antagonist DES reversed the effects of oestrogen. Therefore, we investigated the ERR $\beta$ localisation under oestrogen and DES treatment (Figure 4A); no nuclear fragmentation was observed following either treatment; interestingly remarkable blockage in $\operatorname{ERR} \beta$ nuclear translocation was observed under DES treatment.

Confirmation of $\operatorname{ERR} \beta$ and $\operatorname{ER} \alpha$ involvement in the regulation of BCAS2 and FST in MCF-7 cells. Real-time PCR data (Figure 4B) and western blots (Figures 4C-I and II) of $17 \beta$-oestradiol or ICI182780 in DES-treated MCF-7 cells confirmed the involvement of $\mathrm{ERR} \beta \mathrm{LBD}$ and $\mathrm{ER} \alpha$ in the regulation of BCAS2 and FST.
Follistatin was upregulated as a result of $10 \mathrm{~nm}$ oestrogen treatment, which was reversed with ICI182780 treatment. Breast cancer amplified sequence 2 was downregulated in the presence of oestradiol (E2), and ICI182780 reversed this effect in MCF-7 cells. These results revealed the involvement of ER $\alpha$ in BCAS2 and FST regulation.

However, DES treatment revealed rather complex regulation of BCAS2 and FST by ERR $\beta$. Diethylstilbestrol-mediated inhibition of $\operatorname{ERR} \beta$ nuclear translocation downregulated FST at the mRNA and protein levels, although BCAS2 expression was enhanced compared with the control. Therefore, the antagonistic activity of DES on endogenous $\operatorname{ERR} \beta$ transcriptional activity is questionable for BCAS2 expression. One explanation may lie in the functional domain of endogenous $\operatorname{ERR} \beta$, which differentiates between oestrogen signalling and DES signalling. It seems, endogenous $\operatorname{ERR} \beta$ may not specifically upregulate BCAS2 upon overexpression; rather, it should actually downregulate BCAS2 due to which DES is able to upregulate its expression. We aligned the used sequence (full length) with the available full-length $\operatorname{ERR} \beta$ mRNA sequence through the NCBI and showed that approximately 78 amino acids of the exogenous sequence were deleted in the $\mathrm{F}$ domain (dimer interface; data not shown). Exogenous ERR $\beta$ in MCF-7 cells alone seemed unable to translocate to the nucleus during DES treatment unless the ERs were also transfected exogenously. We next 
A

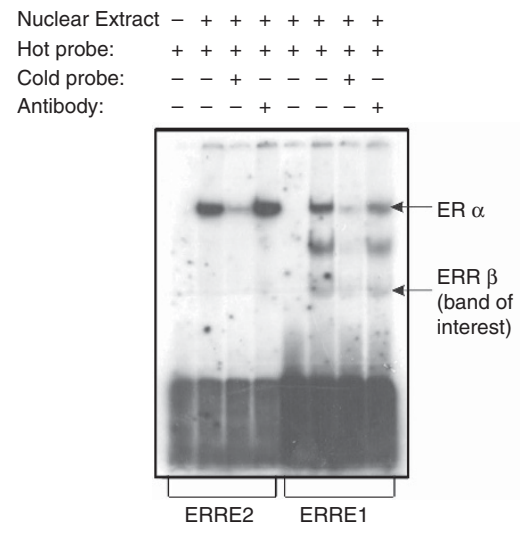

C

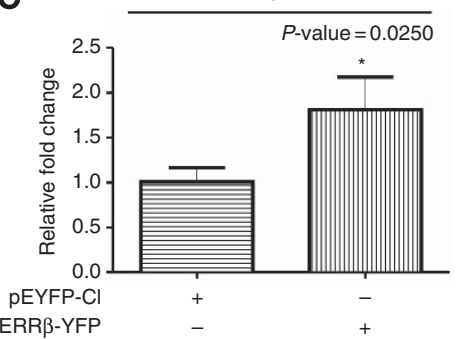

B
$+++$

$+++$

$-+-$

$--+$

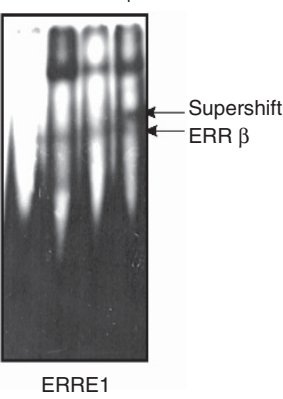

ERRE1

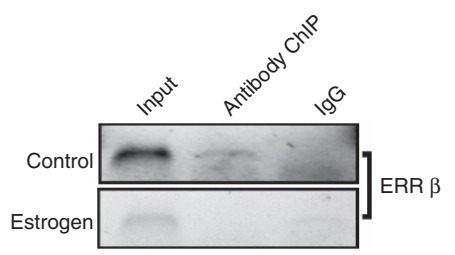

D

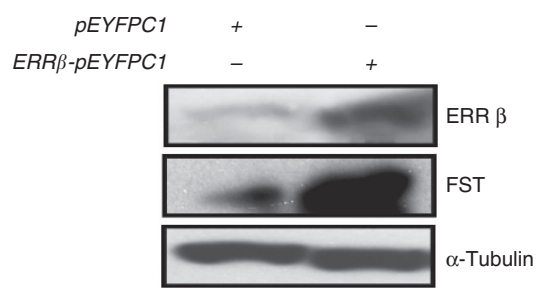

Figure 3. FST as a transcriptional target of ERR $\beta$. (A) Electrophoretic mobility shift assay showing the in vitro binding of transcription factors in ERREs of the FST promoter and supershift confirming ERR $\beta$ binding in ERRE1. (B) Chromatin immunoprecipitation confirming the in vivo ERR $\beta$ binding to FST ERRE1 in MCF-7 cells. (C) Real-time PCR data showing the upregulation of FST transcripts under ERR $\beta$ overexpression. Asterisks $\left(^{*}\right)$ indicates significance (t-test compared with control; $\left.P<0.05\right)$. (D) Western blot confirming the upregulation of FST protein expression under ERR $\beta$ overexpression.

\section{Table 2. EMSA oligos}

\begin{tabular}{|l|l|}
\hline Primer name & Sequence $\left(\mathbf{5}^{\prime} \mathbf{-} \mathbf{3}^{\prime} \mathbf{)}\right.$ \\
\hline FST ERRE1 $\mathrm{F}$ & GTGCTAAAGGTCACACACAG \\
\hline FST ERRE1 R & CTGTGTGTGACCTTTAGCAC \\
\hline FST ERRE2 F & TTACAGCTAAAGGTCACTTC \\
\hline FST ERRE2 R & GAAGTGACCTTTAGCTGTAA \\
\hline BCAS2 ERRE F & GAAAAGTGGAGTTAAAGGTCAGTTTCATTA \\
\hline BCAS2 ERRE R & TAATGAAACTGACCTTTAACTCCACTTTTC \\
\hline $\begin{array}{l}\text { Abbreviations: BCAS2 }=\text { breast cancer amplified sequence 2; EMSA = electrophoretic } \\
\text { mobility shift assay; FST }=\text { Follistatin. }\end{array}$ \\
\hline
\end{tabular}

examined whether the release of $\operatorname{ERR} \beta$ from ERRE following E2 treatment occurred because of competition with ER $\alpha$ using ChIP (Figure 4D) since only ER $\alpha$ shared ERREs as common binding sites with ERRs. FST distal ERRE and BCAS2 ERRE showed ER $\alpha$ binding in vehicle-treated samples. Surprisingly, E2 treatment resulted in the release of $\mathrm{ER} \alpha$ as well from ERREs indicating $\mathrm{ER} \alpha$ AF-1 domain (ligand independent) is responsible for regulating FST and BCAS2 expressions at basal level in MCF-7 and convergence of the $\operatorname{ER} \alpha$ and $\operatorname{ERR} \beta$ signaling pathways involving BCAS2 and FST.

The $3 \mathrm{D}$ structural model of the $\operatorname{ERR} \beta$ homo sapiens protein 508AA was built using I-TASSER. The docking of ERR $\beta$ with ER $\alpha$ and $\operatorname{ERR} \beta$ with $\operatorname{ER} \beta$ was performed using Z-dock. Preliminary modelling showed that ER $\alpha$ binds to the D domain and partially the LBD of ERR $\beta$. The residues Arg179, 182, Lys184, Arg187, Ile201, Pro233, Glu372, Gln375, Asp376 and Glu234 of ERR $\beta$
Table 3. ChIP primers

\begin{tabular}{|l|l|}
\hline Primer name & Sequence $\left(\mathbf{5}^{\prime} \mathbf{- 3} \mathbf{3}^{\prime}\right)$ \\
\hline BCAS2 ERRE F & TTTTGTGGAGTTGGTAGGAC \\
\hline BCAS2 ERRE R & CTCATGTTGGTGAAACTGTG \\
\hline FST ERRE 1 F & TGCCTTCTCCTGGCTAACCCCT \\
\hline FST ERRE 1 R & GCATCCACCAGAAGGGCTAGTGC \\
\hline $\begin{array}{l}\text { Abbreviations: BCAS2 = breast cancer amplified sequence 2; ChIP }=\text { chromatin immuno- } \\
\text { precipitation; FST }=\text { Follistatin. }\end{array}$ \\
\hline
\end{tabular}

and Leu327, Tyr328, Arg352, Val355, His356, Ile358, Asn532, Pro535, Asp538 and Glu542 of ER $\alpha$ were found at the interface (Figure 5A). The residues of ER $\alpha$ that seemed to be part of the docking interface included a domain involved in the interaction with AKAP13 and the self-association and transactivation of the LBD region.

According to the ChIP assays, $\mathrm{ER} \alpha$ and $\operatorname{ERR} \beta$ simultaneously regulate BCAS2 and FST in an ERRE-dependent manner, and we therefore examined whether the transcription factor colocalises in MCF-7 cells using the overexpression of fluorescent constructs of $\operatorname{ERR} \beta \mathrm{L}$ and $\mathrm{ER} \alpha$. Oestrogen-related receptor- $\beta$ colocalised with $\mathrm{ER} \alpha$ in the nucleus of MCF-7 cells (Figure 5B). ER $\alpha$ always colocalised with ERR $\beta$ in co-transfection experiments in vehicle-, E2and DES-treated cells.

The 3D structural modelling study and confocal microscopy suggested the occurrence of possible interactions between $\mathrm{ER} \alpha$ and ERR $\beta$. In vivo CoIP experiments confirmed these results (Figure 5C), whereas oestrogen treatment compromised this interaction. 
A

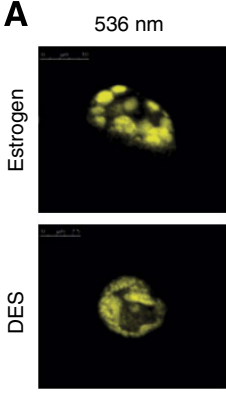

$647 \mathrm{~nm}$

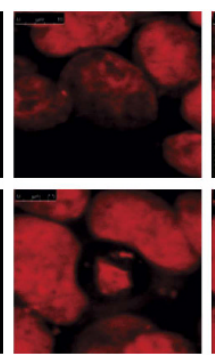

C I

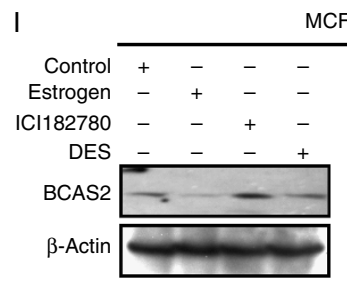

Merged

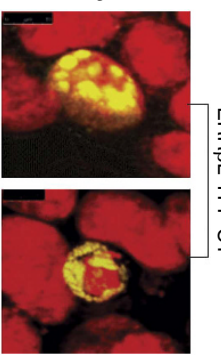

B

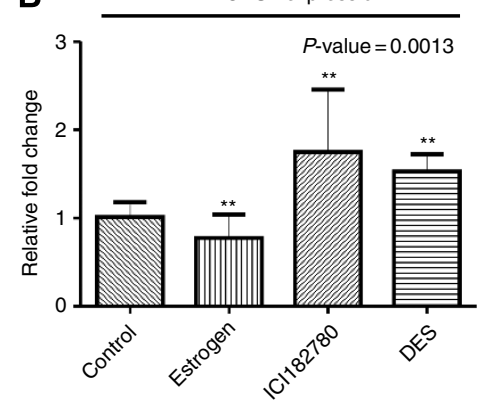

FST expression

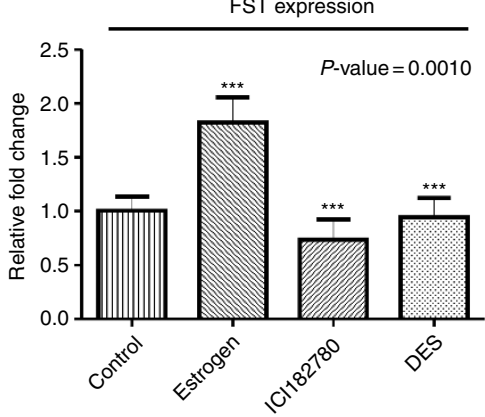

II

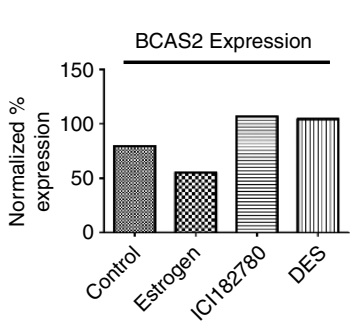

D

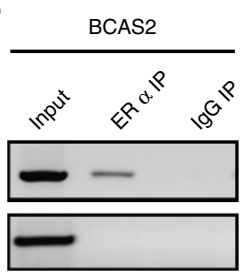

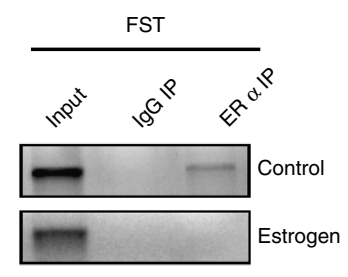

Figure 4. Involvement of ERs on the regulation of ERR $\beta$ transcriptional targets. (A) Effect of oestrogen and DES treatment on exogenously overexpressed ERR $\beta$ intracellular translocation as shown by confocal microscopy in MCF-7 cells. (B) Effect of 24-h treatment with E2, the pure ER antagonist ICl182780 and the ERR $\beta$ antagonist DES on BCAS2 and FST transcription using real-time PCR. Asterisks $\left({ }^{*}\right)$ indicates significance (one way ANOVA test compared with control; P<0.05). (C-I) Effect of 24-h treatment with E2, the pure ER $\alpha$ antagonist ICI182780 and the ERR $\beta$ antagonist DES on BCAS2 and FST protein expression using western blotting. (II) Densitometric analysis of the BCAS2 panel. (D) Chromatin immunoprecipitation PCR confirming the recruitment of ER $\alpha$ to the respective ERRE sites of BCAS2 and FST in MCF-7 cells.

A

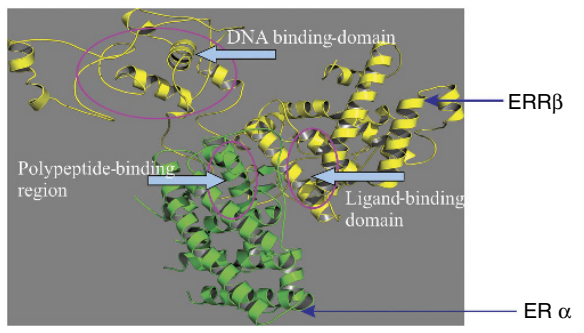

C
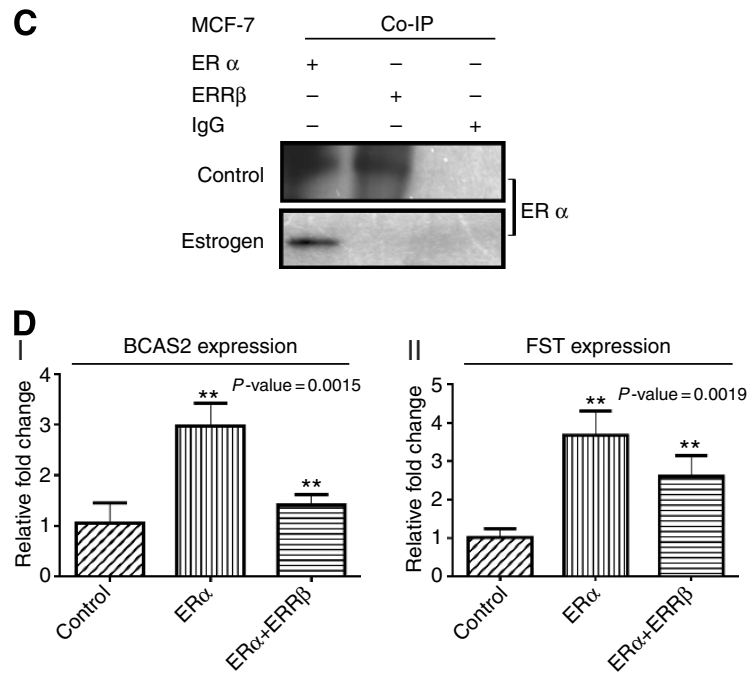
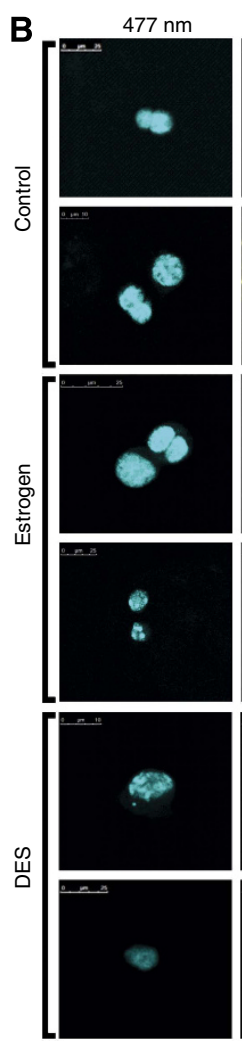
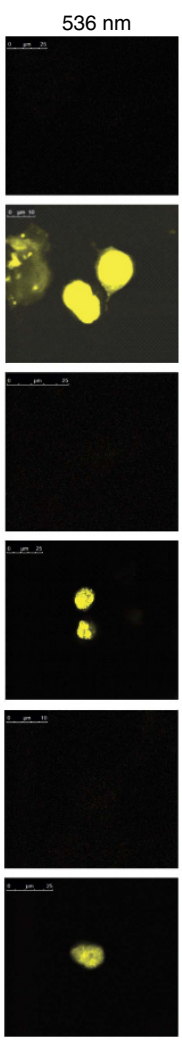

$647 \mathrm{~nm}$
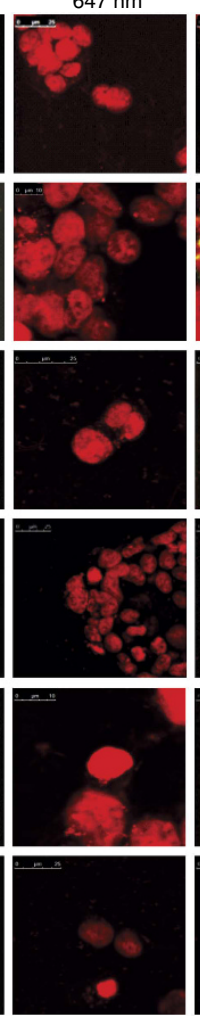

Merged
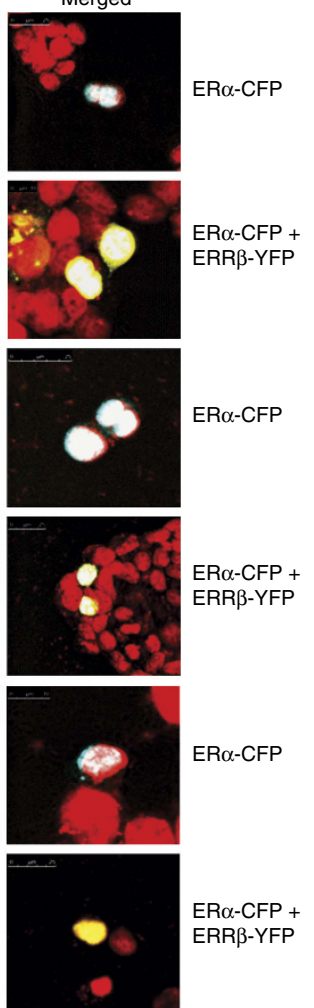

Figure 5. Modulation of ER $\alpha$ functional activity by ERR $\beta$. (A) 3D structural model predicting the physical interaction of ER $\alpha$ (green) with ERR $\beta$ (yellow). (B) Intracellular localisation of exogenously overexpressed ER $\alpha$ alone and ERR $\beta$ under different treatment conditions in MCF-7 cells using confocal microscopy. (C) Co-immunoprecipitation assay showing the physical interactions between ER $\alpha$ and ERR $\beta$ in vehicle- and oestrogentreated cells. (D) Real-time PCR data showing mRNA expression patterns of BCAS2 (I) and FST (II) under ER $\alpha$ overexpression alone and ER $\alpha$ with ERR $\beta$ in MCF-7 cells. Asterisks ${ }^{*}$ ) indicates significance (one way ANOVA test compared with control; $P<0.05$ ). 
The interactions of $\operatorname{ERR} \beta$ with $\mathrm{ER} \alpha$ led us to perform real-time PCR to investigate the expression of the common targets BCAS2 and FST following co-transfection of ER $\alpha$ and ERR $\beta$. Oestrogen-related receptor- $\beta$ significantly reduced the upregulation of BCAS2 and FST by $\mathrm{ER} \alpha$ (Figures 5D-I and II). Real-time figures showing these

\section{Table 4. Real-time PCR primers}

\begin{tabular}{|c|c|}
\hline Primer name & Sequence $\left(5^{\prime}-3^{\prime}\right)$ \\
\hline BCAS2 RT primer F & GAAACGATATGAGCTTCCAG \\
\hline BCAS2 RT primer $\mathrm{R}$ & CATTACATCCATGCTGTGACG \\
\hline FST RT primer $\mathrm{F}$ & GGGAGAGGCCGGTGTTCCCT \\
\hline FST RT primer $\mathrm{R}$ & TGGGGGAATACAGGGGAGCTGT \\
\hline ERR $\beta$ RT primer $\mathrm{F}$ & AAGCCATTGACCAAGATTGT \\
\hline ERR $\beta$ RT primer $\mathrm{R}$ & GGTCACAGAGAGTGGTCAGG \\
\hline ER $\alpha$ RT primer $F$ & AGCTCCTCСTCATCCTCTCC \\
\hline ER $\alpha$ RT primer $\mathrm{R}$ & TCTCCAGCAGCAGGTCATAG \\
\hline ER $\beta$ RT primer $\mathrm{F}$ & TTCCCAGCAATGTCACTAACTT \\
\hline ER $\beta$ RT primer $\mathrm{R}$ & TTGAGGTTCCGCATACAGA \\
\hline 5'hMMP7 Ex2 & TGGCCTACCTATAACTGGAA \\
\hline 3'hMMP7 Ex2 & GTAGGTGACCACTTTGGAAG \\
\hline
\end{tabular}

transfections are shown in Supplementary Figures 2B-I, II and III. The primers used to examine the transfections are listed in Table 4.

The docking results of $\operatorname{ER} \beta$ with $\operatorname{ERR} \beta$ showed that $\operatorname{ER} \beta$ binds to $\operatorname{ERR} \beta$ at the $\operatorname{LBD}$ of $\operatorname{ERR} \beta$. The residues $\operatorname{Arg} 400, \operatorname{Gln} 401$, Ala404 Gln408, Tyr411 and Leu429 from ERR $\beta$ and Met379 and Ala456, Met460, Ser463, His467 and Lys471 from ER $\beta$ were found at the docking interface (Figure $6 \mathrm{~A}$ ). The $\operatorname{ER} \beta$ residues at the docking interface include a domain that is involved in dimerisation interface/polypeptide binding. Based on our CoIP results, we extended our study towards colocalization pattern of $\operatorname{ER} \beta$ and $\operatorname{ERR} \beta$ with fluorescent constructs. $\operatorname{ER} \beta$ demonstrated predominantly nuclear localisation under vehicle, E2 and DES treatment and with $\operatorname{ERR} \beta$ co-transfection in MCF-7 cells (Figure 6B).

In contrast to MCF-7 cells, MDA MB 231 cells, which exhibit distinct $\operatorname{ER} \beta$ expression but lack $\mathrm{ER} \alpha$ expression (Li et al, 2010), restrict $\operatorname{ERR} \beta$ functionality leading to the failure of exogenous $\operatorname{ER} \alpha$ translocation to the nucleus. Therefore, we investigated whether the dependence of $\mathrm{ER} \alpha$ nuclear translocation on $\operatorname{ERR} \beta$ in the presence of oestrogen was based on a physical interaction using CoIP assays. We also performed CoIP of $\operatorname{ERR} \beta$ with $\operatorname{ER} \beta$ because of the structural similarities between $\operatorname{ER} \alpha$ and $\operatorname{ER} \beta$ (Nilsson et al, 2001). Interestingly, $\operatorname{ERR} \beta$ was more interactive with $\operatorname{ER} \beta$ in vivo compared with ER $\alpha$ in MCF-7 cells (Figures 5C and 6C). However, these interactions were compromised following oestrogen treatment. Oestrogen-related receptor- $\beta$ also interacted with $\operatorname{ER} \beta$ in MDA MB 231 cells, and this interaction was reduced as a result of oestrogen treatment.

Oestrogen receptor- $\beta$ exhibited greater affinity for $\operatorname{ERR} \beta$ than ER $\alpha$. Therefore, we performed the same co-transfection
A

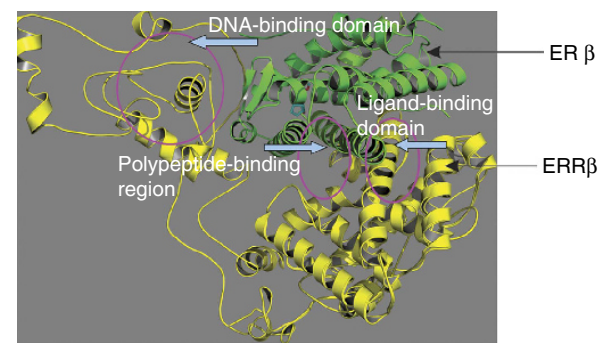

C

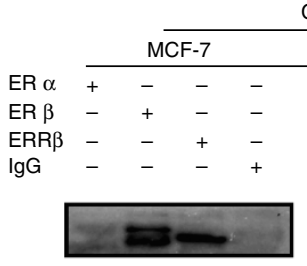

Co-IP

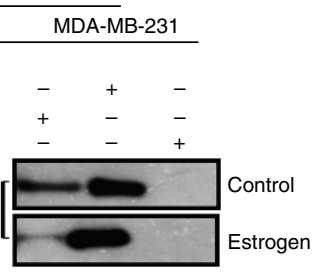

D
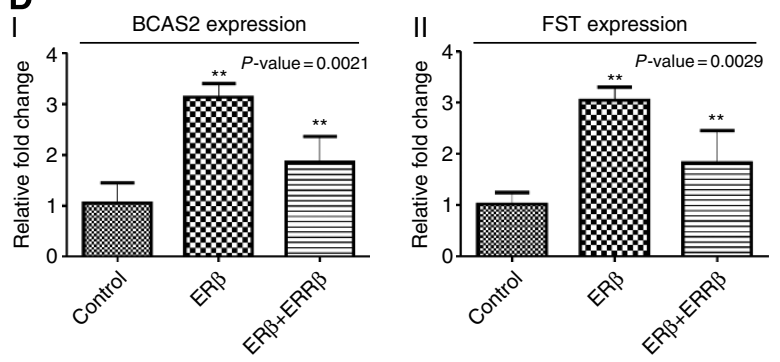

B
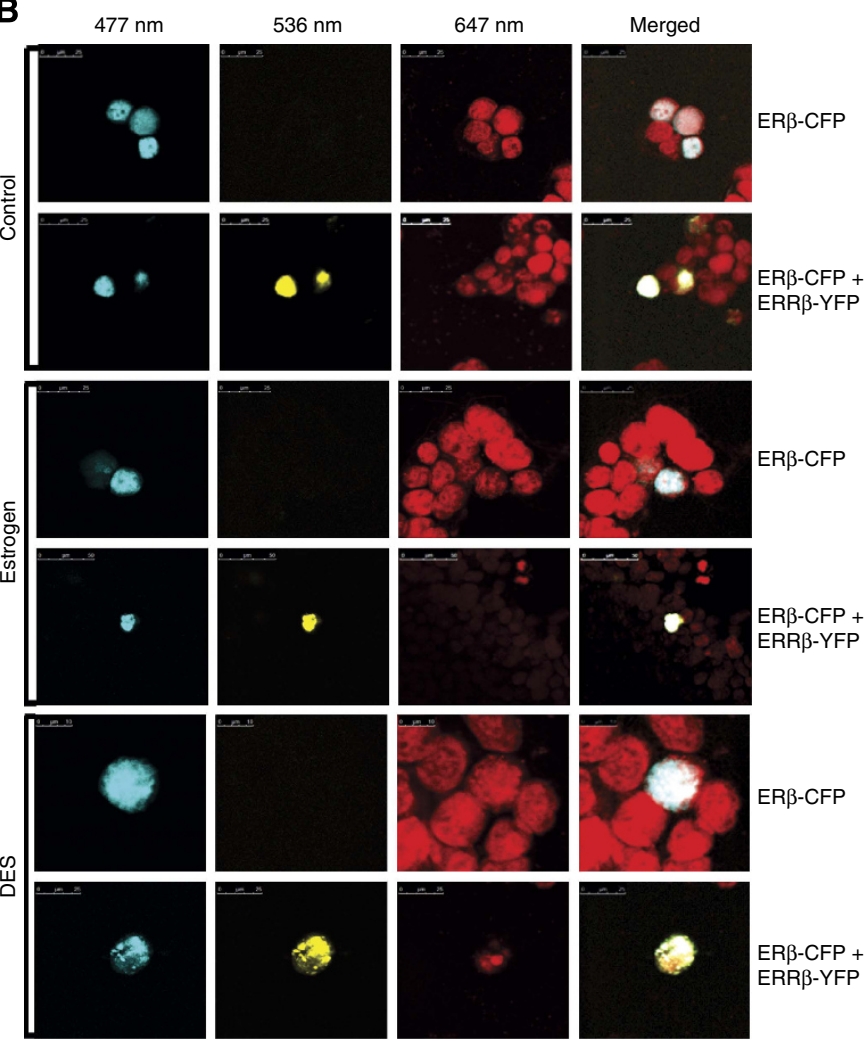

Figure 6. Modulation of ER $\beta$ functional activity by ERR $\beta$. (A) 3D structural model predicting the physical interactions of ER $\beta$ (green) with ERR $\beta$ (yellow). (B) Intracellular localisation of exogenously overexpressed ER $\beta$ alone and with ERR $\beta$ under different treatment conditions in MCF-7 cell line using confocal microscopy. (C) Co-immunoprecipitation assay showing the physical interactions between ER $\beta$ and ERR $\beta$ in MCF-7 and in MDA-MB-231 (lacking ER $\alpha$ ) cells following vehicle and oestrogen treatments. (D) Real-time PCR data showing mRNA expression patterns of BCAS2 (I) and FST (II) under ER $\alpha$ overexpression alone and with ERR $\beta$ in MCF-7 cells. Asterisks (*) indicates significance (one way ANOVA test compared with control; $P<0.05)$. 
experiment described above using $\operatorname{ER} \beta$. Oestrogen receptor- $\beta$ mediated activation of BCAS2 and FST expression was reduced following ERR $\beta$ co-transfection, similar to ER $\alpha$ (Figures 6D-I and II).

Triple-negative MDA MB 231 cells showing different patterns of FST and BCAS2 regulation depict the role of $\operatorname{ERR} \beta$ as a coregulator of ERs for the regulation of ERRE-containing transcriptional target genes. MDA MB 231 cells, which are ER $\alpha$ null, uniquely regulate ER $\alpha$ target genes using $\operatorname{ER} \beta$ because of its functional dissimilarity (Nilsson et al, 2001). We also observed different $\operatorname{ER} \beta$ regulation patterns of our specified target genes, BCAS2 and FST, in MDA MB 231 cells in western blots of treated samples (Supplementary Figure 3A). For example, BCAS2 was downregulated in oestrogen-treated cells, and ICI182780 did not reverse this downregulation, which confirmed ER $\beta$ involvement. A similar effect was observed for FST expression. Diethylstilbestrol also downregulated BCAS2 and FST, which indicated the agonistic activity of DES on $\operatorname{ER} \beta$ and the inhibition of the transcriptional activity of $\operatorname{ERR} \beta$. This experiment also demonstrated that in the absence of oestrogen, ERR $\beta$ acted as a necessary coregulator of ERs to regulate the expression of ERRE-containing transcriptional target genes, such as BCAS2 and FST.

We next performed confocal experiments to explore the effect of $\operatorname{ERR} \beta \mathrm{L}$ on exogenous $\mathrm{ER} \alpha$ localisation in more aggressive MDA MB 231 cells (Supplementary Figure 3B). Surprisingly, exogenous $\mathrm{ER} \alpha$ in cells receiving the vehicle control, oestrogen or DES treatment did not demonstrate nuclear localisation, and this cytoplasmic localisation did not change under conditions of $\operatorname{ERR} \beta \mathrm{L}$ overexpression. Moreover, ERR $\beta \mathrm{L}$ overexpression did not affect $\operatorname{ER} \beta$ cytoplasmic localisation following oestrogen treatment or DES treatment in MDA MB 231 cells, which indicated a major inhibitory mechanism in the nuclear translocation of ERs.

$\mathrm{ERR} \beta, \mathrm{BCAS} 2$ and FST show differential $\mathrm{mRNA}$ and protein expression patterns following time-dependent oestrogen treatment. Oestrogen-related receptor- $\beta$ overexpression transactivated BCAS2 and FST which indicated that the effect on cellular metabolism because of their transactivation was directed in the same direction. However, the mechanism for this differential
A
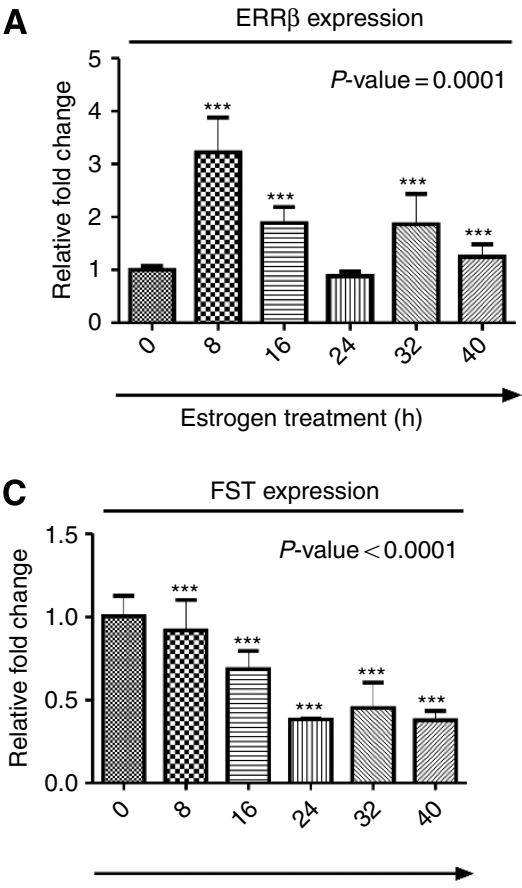

Estrogen treatment $(\mathrm{h})$

E

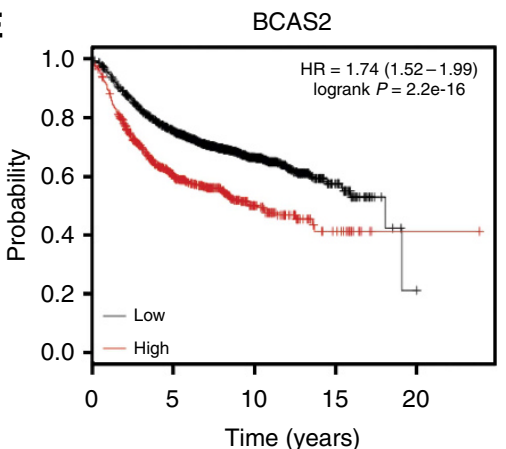

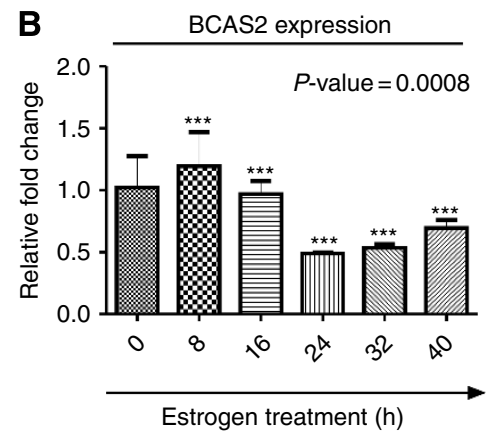

D

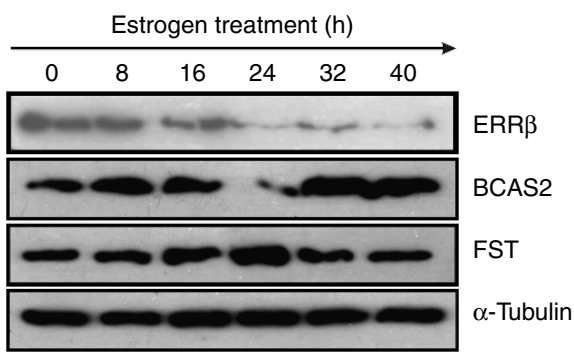

$\mathbf{F}$

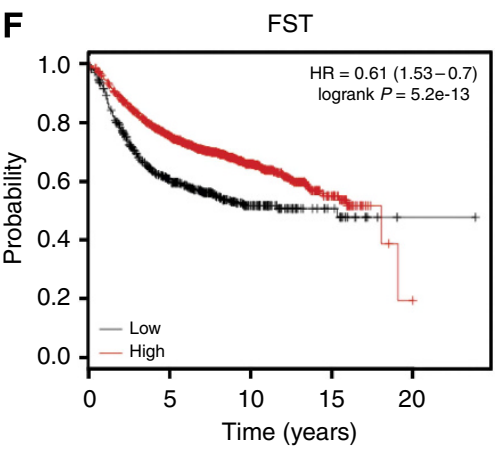

Figure 7. Effect of oestrogen on ERR $\beta$ transcriptional targets, their interconnected signalling events and patient prognosis. (A, B and C) Real-time PCR data showing time-dependent expression patterns of ERR $\beta, B C A S 2$ and FST, respectively. Asterisks $\left(^{*}\right)$ indicates significance (one way ANOVA test compared with control; $P<0.05$ ). (D) Western blot showing time-dependent protein expression patterns of ERR $\beta$, BCAS2 and FST. (E and F) Kaplan-Meier plotter analyses showing the associations between low BCAS2 and high FST expression with better prognosis and longer relapse-free survival, respectively. 
oestrogen-driven regulation of the above-mentioned genes is not known. Therefore, we investigated whether this regulation was altered in a time-dependent manner. Real-time PCR data (Figures 7A-C) showed similar expression patterns for BCAS2 and FST in response to oestrogen, whereas western blot data (Figure 7D) showed different expression patterns. Breast cancer amplified sequence 2 protein expression was stably upregulated after $32 \mathrm{~h}$, but FST protein expression returned to basal levels after a transient increase at $16-24 \mathrm{~h}$. Breast cancer amplified sequence 2 protein expression was at its lowest level at $\sim 24 \mathrm{~h}$, whereas FST protein expression was highest during this time. Moreover, the mRNA and protein expression of $\operatorname{ERR} \beta$ was not necessarily correlated with BCAS2 or FST expression. For example, ERR $\beta$ protein expression was downregulated $24 \mathrm{~h}$ after E2 treatment. It seemed that oestrogen-related receptor- $\beta$ was subjected to some type of protein degradation event during long-term E2 treatment, which also downregulated BCAS2 and FST transcription. However, the stability of BCAS2 protein was also restored after long-term E2 treatment.

BCAS2 and FST exhibit opposite prognostic effects in breast cancer patients. Follistatin is a potential anti-proliferative molecule that is expressed at the highest level, whereas BCAS2 is completely downregulated, after 24-h E2 treatment. Therefore, we investigated the correlation between BCAS2 and FST expression with prognosis in clinical breast cancer patient samples $(n=2978)$ using KM plotter analysis. This analysis revealed improved relapsefree survival in FST-overexpressing patients compared with those with lower expression (Figure 7F). In contrast, lower BCAS2 expression was associated with higher relapse-free survival (Figure 7E).

BCAS2 downregulates FST expression through the inhibition of $\beta$-catenin/TCF4 signalling. Kaplan-Meier plotter analyses showed an inverse correlation between BCAS2 and FST. Therefore, we speculated that BCAS2, which is a known coregulator molecule by nature, may regulate FST. We performed real-time PCR for FST following BCAS2 knockdown in MCF-7 cells and observed significantly upregulated FST expression, which underscored the proliferative nature of BCAS2 (Figure 8A). However, knockdown of FST did not affect BCAS2 (Figure $8 \mathrm{~B}$ ), and this negative result confirmed that no downstream pathway of FST regulates BCAS2. Confirmation of siRNA transfection is shown in Supplementary Figures 4A-I and II. Sequences of the siRNAs used are listed in Table 5. Follistatin upregulation at the protein level following BCAS2 knockdown was also demonstrated using western blots (Figure 8C). In particular, we performed western blotting of FST after BCAS2 knockdown in the presence of tamoxifen (Figure 8C) and found that BCAS2-mediated regulation of FST remained intact, which supported the non-involvement of ERs.

ER coregulator BCAS2, as per our real time data acts as an inhibitor of FST. The E2 target gene (Pontes et al, 2010) $\beta$-catenin is a novel prognostic marker in breast cancer (Lin et al, 2000) and an upstream regulator of FST (Lin et al, 2000). Therefore, we investigated $\beta$-catenin expression following BCAS2 overexpression and observed that $\beta$-catenin expression was reduced following BCAS2 overexpression (Figure $8 \mathrm{D}$ ). In addition, $\beta$-catenin overexpression upregulated FST (Figure $8 \mathrm{E}$ ). Therefore, BCAS2 likely acts as a negative regulator of the $\beta$-catenin promoter, and downstream FST transcription is blocked as a result.

The downregulation of $\beta$-catenin by BCAS2 led us to further evaluate the regulation of downstream FST (Singh et al, 2009). However, knockdown of $\beta$-catenin reduced the luciferase activity of FST promoter fragments $(2.9 \mathrm{~kb})$ containing eight TCF-4Ebinding sites located $\sim 2870,2329,2298,1823,1803,1387,828$ and 671-bp upstream of the TSS (Figure 8F). Follistatin upregulation also upregulated uncleaved E-cadherin (Figure $8 \mathrm{E}$ ).

BCAS2 upregulated MMP7 and resulted in E-cadherin cleavage, which was counteracted by FST. We next investigated the E-cadherin protein expression level using western blotting to
A

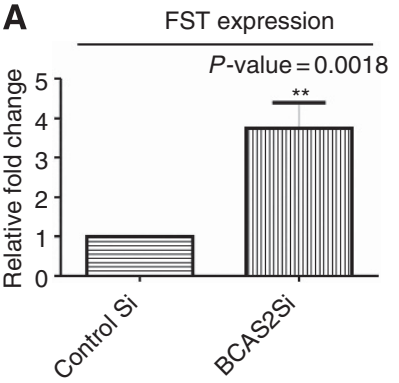

D

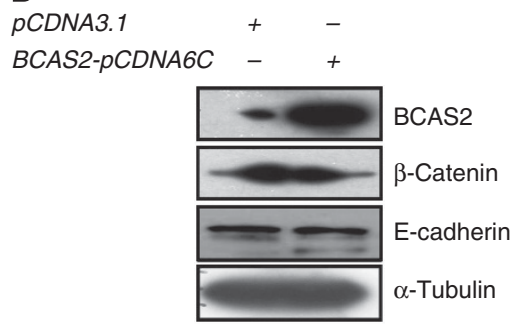

B

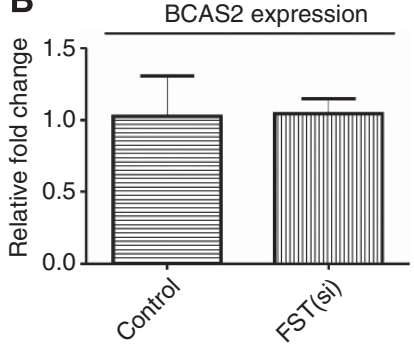

E

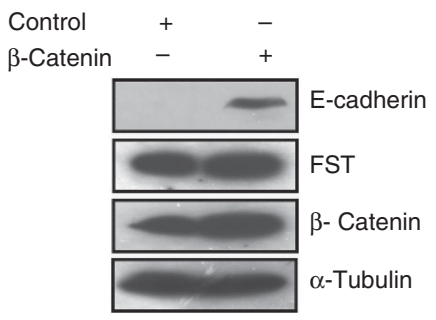

C

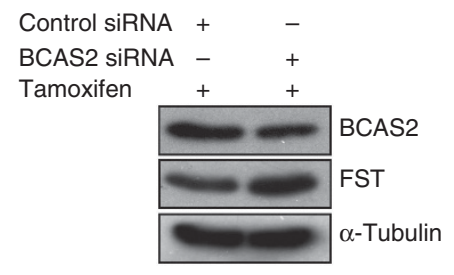

$\mathbf{F}$

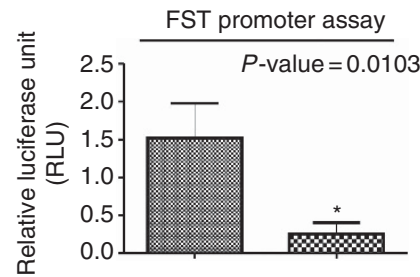

FST-pGL3 + +

Figure 8. ER-independent regulation of FST by BCAS2 and the effect on E-cadherin. ( $A$ and $\mathbf{B}$ ) Real-time PCR data showing FST and BCAS2 transcripts in BCAS2 and FST knockdown samples, respectively. Asterisks ( $\left.{ }^{*}\right)$ indicates significance ( $t$-test compared with control; $P<0.05$ ). (C) Western blot confirming the regulation of FST by BCAS2 irrespective of the presence of the general ER antagonist tamoxifen. (D) Western blot showing the downregulation of $\beta$-catenin and cleavage of E-cadherin under BCAS2 overexpression. (E) Western blot showing FST and E-cadherin upregulation under $\beta$-catenin overexpression. (F) Dual luciferase assay data showing the downregulation of luciferase activity of the TCF4-binding site containing FST promoter fragment in control vs the $\beta$-catenin knockdown sample. Abbreviation: TCF4=transcription factor 4. 
determine the effect of BCAS2 overexpression on cell-cell adhesion mechanisms. An $\sim 80 \mathrm{kDa}$ cleavage product of E-cadherin was observed in the BCAS2 overexpression sample (Figure 8D). We searched for the molecules responsible for E-cadherin cleavage and identified matrix metalloprotease 7 (MMP7), a molecule downstream of FST. Breast cancer amplified sequence 2 upregulated MMP7 expression (Figure 9A), and FST downregulated MMP7 expression as expected (Figure 9B). However, ERR $\beta$ overexpression did not balance the opposite effects of FST and BCAS2 on MMP7

\section{Table 5. siRNAs used}

\begin{tabular}{|l|l|}
\hline Primer name & Sequence $\left(\mathbf{5}^{\prime}-\mathbf{3}^{\prime}\right.$ ) \\
\hline BCAS2 siRNA F & GAAGGAACUUCAGAAGUUA55 \\
\hline BCAS2 siRNA R & UAACUUCUGAAGUUCCUUC55 \\
\hline FST siRNA F & GACCAAUAAUGCCUACUGU55 \\
\hline FST siRNA R & ACAGUAGGCAUUAUUGGUC55 \\
\hline $\begin{array}{l}\text { Abbreviations: BCAS2 = breast cancer amplified sequence 2; FST = Follistatin; siRNA }= \\
\text { small interfering RNA. }\end{array}$ \\
\hline
\end{tabular}

(Figure 9C). This redundant MMP7 activity also led to the cleavage of overexpressed E-cadherin (Figure 9D). The real-time PCR primers for MMP7 are shown in Table 4, and the transfection data are shown in Supplementary Figures 4B (I, II and III).

BCAS2 inhibition of $\beta$-catenin as a result of $\operatorname{ERR} \beta$ overexpression resulted in the blockade of cyclin D1 expression. E-cadherin is a tumour-suppressor gene (Resnitzky et al, 1994; Wong and Gumbiner, 2003), and the mechanism of this suppressor function is mediated through the $\beta$-catenin-binding domain within its cytoplasmic tail. This binding inhibits $\beta$-catenin nuclear localisation and the subsequent transactivation of the cyclin D1 promoter (Lim and Lee, 2002), as cyclin D1 transactivation is required for the G1/S transition in the cell cycle (Resnitzky et al, 1994). As BCAS2 inhibited $\beta$-catenin expression, we hypothesised that cyclin D1 transactivation would also be blocked. Indeed, our western blot data (Figure 9E) supported this hypothesis and showed cyclin D1 downregulation following BCAS2 overexpression. Therefore, E-cadherin overexpression and $\beta$-catenin downregulation under $\operatorname{ERR} \beta$ transfection supports the data of Ariazi et al (2002) by showing that $\operatorname{ERR} \beta$ expression levels are inversely correlated to the S-phase fraction of cells (Ariazi et al, 2002).
A

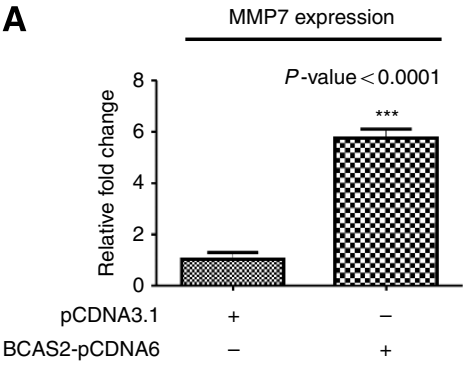

D

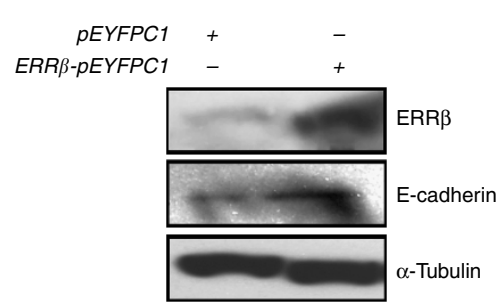

G

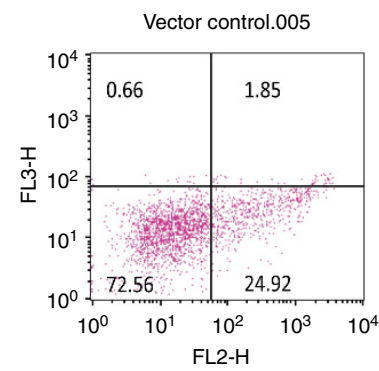

B

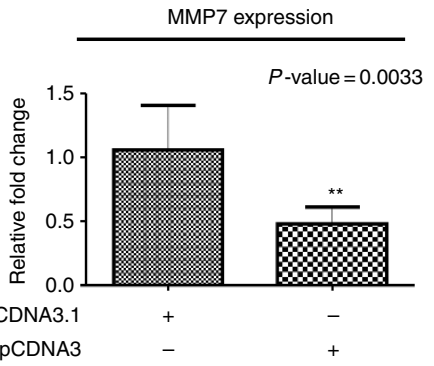

$\mathbf{E}$

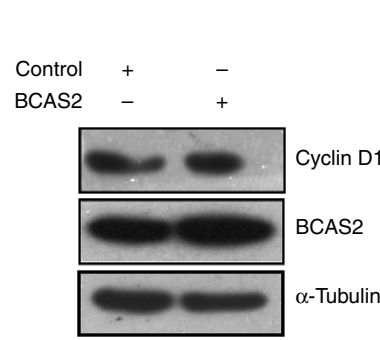

H

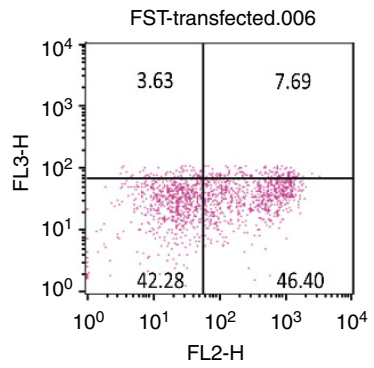

C

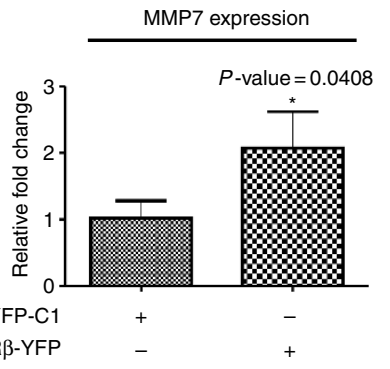

$\mathbf{F}$

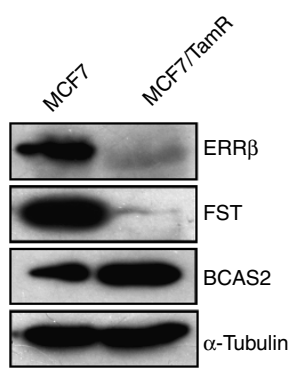

I

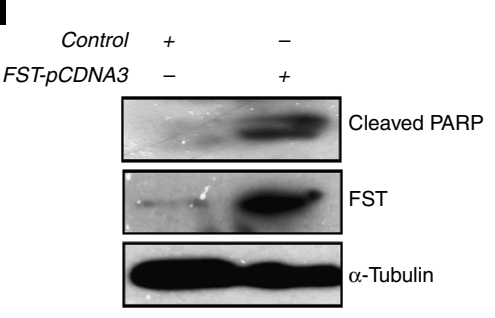

Figure 9. Role of ERR $\beta$ in controlling invasiveness, EMT and apoptosis in breast cancer cells. (A, B and C) Real-time PCR data showing MMP7 mRNA expression under BCAS2, FST and ERR $\beta$ overexpression, respectively. Asterisks $\left(^{\star}\right)$ indicates significance ( $t$-test compared with control; $P<0.05$ ). (D) Western blot showing the upregulation of uncleaved E-cadherin under ERR $\beta$ overexpression. (E) Western blot showing the downregulation of cyclin D1 under BCAS2 overexpression. (F) Western blot showing the overexpression of BCAS2 and the downregulation of ERR $\beta$ and FST in tamoxifen-resistant MCF-7 and MCF-7/ADR cells, respectively. (G and H) Annexin V-PE apoptosis detection assay data showing a significant induction of apoptosis in FST-overexpressing MCF-7 cells (H) compared with vector controls (G). (I) Western blot confirming apoptosis in FST-overexpressing MCF-7 cells via the detection of cleaved PARP. Abbreviations: ADR=adriamycin; PARP = poly ADP ribose polymerase; MMP$7=$ matrix metalloprotease 7 . 
BCAS2 expression is upregulated, whereas $\operatorname{ERR} \beta$ and FST expression is downregulated, in aggressive breast cancer cells. We next investigated BCAS2, FST and $\operatorname{ERR} \beta$ expression in tamoxifen-resistant MCF-7 vs normal MCF-7 cells to evaluate the significance of the crosstalk between protein expression and prognosis in highly aggressive breast cancer cells. Oestrogenrelated receptor- $\beta$ and FST were downregulated and BCAS2 was upregulated in resistant MCF-7 cells compared with normal MCF-7 cells (Figure 9F).

FST overexpression induces apoptosis. Follistatin overexpression induces a sub-G1 population in mammary tumours and an R30C mammary tumour cell line (Krneta et al, 2006). Therefore, we overexpressed FST in MCF-7 cells to investigate its efficiency in apoptosis induction. Follistatin overexpression induced apoptosis in $54.09 \%$ of cells in contrast to $26.77 \%$ induction in the vector control (Figures $9 \mathrm{G}$ and $\mathrm{H}$ ).

We next investigated the expression of cleaved PARP following FST overexpression in MCF-7 cells to further validate the FSTinduced apoptotic signalling pathway. Western blot analyses showed the successful cleavage of PARP under FST overexpression but not in control cells (Figure 9I).

\section{DISCUSSION}

Breast cancer is the most common invasive cancer in women worldwide according to the World Cancer Report and estimates from the International Agency for Research on Cancer (Boyle et al, 2008). Previously, the expression status of certain receptors was adopted for the specific categorisation of invasive breast cancers for targeted therapy, although receptor status was subsequently combined with tumour grade to develop a new approach and improve diagnostics.

The most prevalent subtype of breast cancer is ER-positive tumours (Geyer et al, 2012). Oestrogen receptors and ERRs share some established transcriptional targets, such as pS2, osteopontin and lactoferin, which are used as breast cancer markers because of the structural and functional similarities (Lu et al, 2001; Zhou et al, 2006). Oestrogen-related receptor- $\beta$ function differs from that of $\operatorname{ERR} \alpha$ and $\mathrm{ERR} \gamma$ because of its anti-proliferative nature. Therefore, we studied two of its targets, a probable oncogenic molecule (BCAS2) and a tumoursuppressive molecule (FST), to unravel their differential regulation by $\operatorname{ERR} \beta$ and characterise its precise role in tumourigenesis.

The relative expression of $\operatorname{ERR} \beta$ was higher in an immortalised normal cell line, patients with longer relapse-free survival compared with breast cancer cell lines (ER-positive and ER-negative) and patients with shorter relapse-free survival. Reductions in $\operatorname{ERR} \beta$ expression were observed in vivo in local breast tumour samples with developing malignancy, which indicates the physiological relevance of this receptor. Kaplan-Meier plotter analysis confirmed this difference statistically.

The overexpression of wild-type $\operatorname{ERR} \beta$ significantly induced apoptosis in the MCF-7 breast cancer cell line $(84.53 \%$ vs $2.32 \%$ in controls). One of the significant mediators of this apoptosis is the $\operatorname{ERR} \beta$ transcriptional target, FST (46.40\% early apoptotic induction compared with $24.92 \%$ in control cells). Follistatin inhibits tumourigenesis in R30C breast cancer cells and mouse mammary tumours (Krneta et al, 2006), although the downstream pathways in breast cancer, which are under FST regulation, are not well studied. However, FST is known to inhibit multi-organ metastasis in natural killer cell-deprived SCID mice. Moreover, MCF-7 cells are caspase 3-null (Janicke, 2009), and the $89 \mathrm{kDa}$ cleavage product of PARP demonstrated the activation of alternative effector caspases under FST overexpression. In contrast, BCAS2 is amplified in breast cancer (Maass et al, 2002) which is indicative of its proliferative nature. Supportive evidences include its coactivator role for $\mathrm{ER} \alpha$ and negative regulatory role for $\mathrm{p} 53$ transcriptional target p21. However, the downstream signalling events associated with BCAS2 remain poorly characterised.

We performed KM plotter analyses of BCAS2 and FST to investigate whether the opposite roles of BCAS2 and FST on cellular proliferation may reflect clinically significant differences in prognosis in breast cancer patients. We consistently observed a correlation between high BCAS2 and FST expression and poor and good prognoses, respectively.

Kaplan-Meier plotter analysis data further denoted a possible relationship between BCAS2 and FST signalling pathways. Therefore, we knocked down BCAS2 and performed real-time PCR for FST mRNA expression. Follistatin mRNA was highly upregulated in BCAS2 knockdown samples, which suggests that BCAS2 opposed the anti-proliferative effects of FST through the downregulation of FST mRNA transcription and acted as a negative regulator either directly or indirectly. However, the knockdown of FST did not alter BCAS2 protein levels, which showed that this signalling was not reversible and that FST was downstream of BCAS2. We next investigated whether the regulation of FST by BCAS2 involved ER $\alpha$ by treating MCF-7 cells with the ER antagonist tamoxifen (de Leeuw et al, 2011). Breast cancer amplified sequence 2 regulation of FST remained intact in the presence of tamoxifen, which demonstrated that the regulation was independent of ER. These results indicated that the downregulation of $\beta$-catenin/TCF- 4 signalling on the FST promoter mediated the regulation of FST. In fact, loss of $\beta$-catenin expression is associated with bone metastasis in $82 \%$ of prostate cancer patients (Pontes et al, 2010), and this phenomenon may be assigned to the transcriptional blockade of downstream FST, which inhibits metastasis (Talmadge, 2008). Interestingly, $\mathrm{ERR} \beta$ upregulates BCAS2, which results in the loss of $\beta$-catenin, but $\operatorname{ERR} \beta$ also upregulates FST, which has anti-metastatic effects. The role of E-cadherin as a mediator of cell-cell adhesion also emerges as a potentially important mechanism (Onder et al, 2008) in this context. E-cadherin undergoes proteolysis and produces fragments that promote tumour growth and proliferation (David and Rajasekaran, 2012), and BCAS2 overexpression alone resulted in E-cadherin cleavage in our study. E-cadherin cleavage is also a signal of apoptosis induction (Steinhusen et al, 2001). However, the cleavage that occurred during apoptosis in mentioned study resulted in three fragments of molecular sizes 24,29 and $84 \mathrm{kDa}$ through two distinct proteolytic events because of caspase 3 and a metalloproteinase, likely secretase. Our findings revealed a single cleavage that resulted in a $135-\mathrm{kDa}$ full-length band and an $\sim 80 \mathrm{kDa}$ fragment, which indicated the shredding of the extracellular domain (sE-cad) by $\alpha$-secretase (David and Rajasekaran, 2012). The intracellular fragment containing the transmembrane segment and the cytoplasmic tail could not be examined for further cleavage events because the antibody used was raised against a synthetic peptide corresponding to the fifth cadherin domain of the extracellular segment of E-cadherin. Since, MCF-7 cell line is caspase 3-null (Janicke, 2009), only cleavage by $\gamma$-secretase is possible in the cytoplasmic domain, which remains to explored. The cytoplasmic segment contains a $\beta$-catenin-binding site, and $\beta$-catenin connects E-cadherin to the actin cytoskeleton via $\alpha$-catenin (Ito et al, 1999). Therefore, the downstream $\beta$-catenin signalling events that result in cyclin D1 activation are dependent on the nuclear transport of free $\beta$-catenin, which is hindered by E-cadherin binding. But at least, dissociation of $\beta$-catenin from adherent junctions is confirmed through shredding of E-cadherin extracellular domain supporting positive role of BCAS2 in breast cancer metastasis.

However, $\operatorname{ERR} \beta$ overexpression inhibited this shredding of the E-cadherin extracellular domain despite BCAS2 upregulation. Therefore, we further investigated the mechanism of E-cadherin cleavage inhibition, although the role of FST in E-cadherin regulation requires further investigation. Oestrogen-related receptor- $\beta$ simultaneously upregulated BCAS2 and FST. Follistatin is an 
inhibitor of activin, a TGF $\beta$ superfamily member that is responsible for the upregulation of MMP7 in oesophageal carcinoma cells (Yoshinaga et al, 2008). Matrix metalloprotease 7 is a protease responsible for the cleavage of E-cadherin in nontransformed epithelial cell lines, which results in loss of cell-cell contact, loss of epithelial cell polarisation and increased proliferation via Rho A activation (Lynch et al, 2010). Therefore, FST upregulation may lead to the downregulation of activin-mediated MMP7 upregulation, which inhibits E-cadherin cleavage.

Interestingly, BCAS2 was found to highly counteract this FSTmediated downregulation of MMP7. This counteractive activity surpasses the tumour-suppressive activity of $\operatorname{ERR} \beta$ through FST by promoting the invasiveness induced by MMP7 in breast cancer cells, such as MCF-7 (Wang et al, 2006).

Our experimental findings also revealed E-cadherin upregulation in ERR $\beta$-overexpressing samples. As the FST-target, activin, binds to type II activin receptors, which phosphorylate R-SMADs and SMAD2/SMAD3 (Chen et al, 2006), this complex may interact with coSMAD-SMAD4 and downregulate E-cadherin transcription (Vincent et al, 2009). Therefore, E-cadherin expression was increased when FST blocked the activin-mediated SMAD cascade.

In this study, we have tried to explore the effect of ERs and $\operatorname{ERR} \beta$ on BCAS2 and FST transcription. Our findings indicate that $\operatorname{ERR} \beta$ overexpression upregulates BCAS2 and FST expression at the mRNA and protein levels and reduces the ER-mediated transactivation of both genes, as demonstrated from our real-time PCR data. While, the FST protein level increases when ER and ERR $\beta$ interactions are abrogated as a result of 24-h E2 treatment, BCAS2 regulation is unique, as the maintenance of BCAS2 transcripts at the basal level requires the binding of ERs and $\operatorname{ERR} \beta$. Therefore, the interaction of ER with $\operatorname{ERR} \beta$ was lost when oestrogen occupies the ER LBD (24-h E2 treatment), and the BCAS2 protein level decreased as a consequence of the lack of this physical interaction.

In light of these results, we also evaluated the interaction of ERs with $\operatorname{ERR} \beta$ and the effect of the function of the $\operatorname{ERR} \beta$ DNAbinding domain (DBD). Our 3D structural modelling data showed that $\mathrm{ER} \alpha$ binding did not disturb the $\mathrm{ERR} \beta \mathrm{DBD}$, whereas $\operatorname{ER} \beta$ binding did. Therefore, ERR $\beta$ and $\operatorname{ER} \alpha$ remain bound directly or indirectly to the DNA sequence flanking the concerned ERREs. In contrast, since oestrogen receptor- $\beta$ binding to $\operatorname{ERR} \beta$ may disturb the $\operatorname{ERR} \beta \mathrm{DBD}$, therefore, co-recruitment of $\operatorname{ER} \beta$ and $\operatorname{ERR} \beta$ on same response element appears to be infeasible.

Overall, our study revealed the involvement of $\operatorname{ERR} \beta$ in oestrogen signalling and provided sound mechanistic insights into ERR $\beta$-regulated downstream pathways (Figure 10). Oestrogenrelated receptor- $\beta$ mediated induction of FST clearly supports its ability to induce apoptosis. However, BCAS2 upregulation, which is otherwise proliferative, is directed towards the downregulation of $\beta$-catenin, which results in the blockade of the G1 to S transition. The novelty of this finding is that a tumour suppressor was shown to convert the activity of an oncogene into a favourable outcome. Finally, the ERR $\beta$-mediated upregulation of E-cadherin may serve

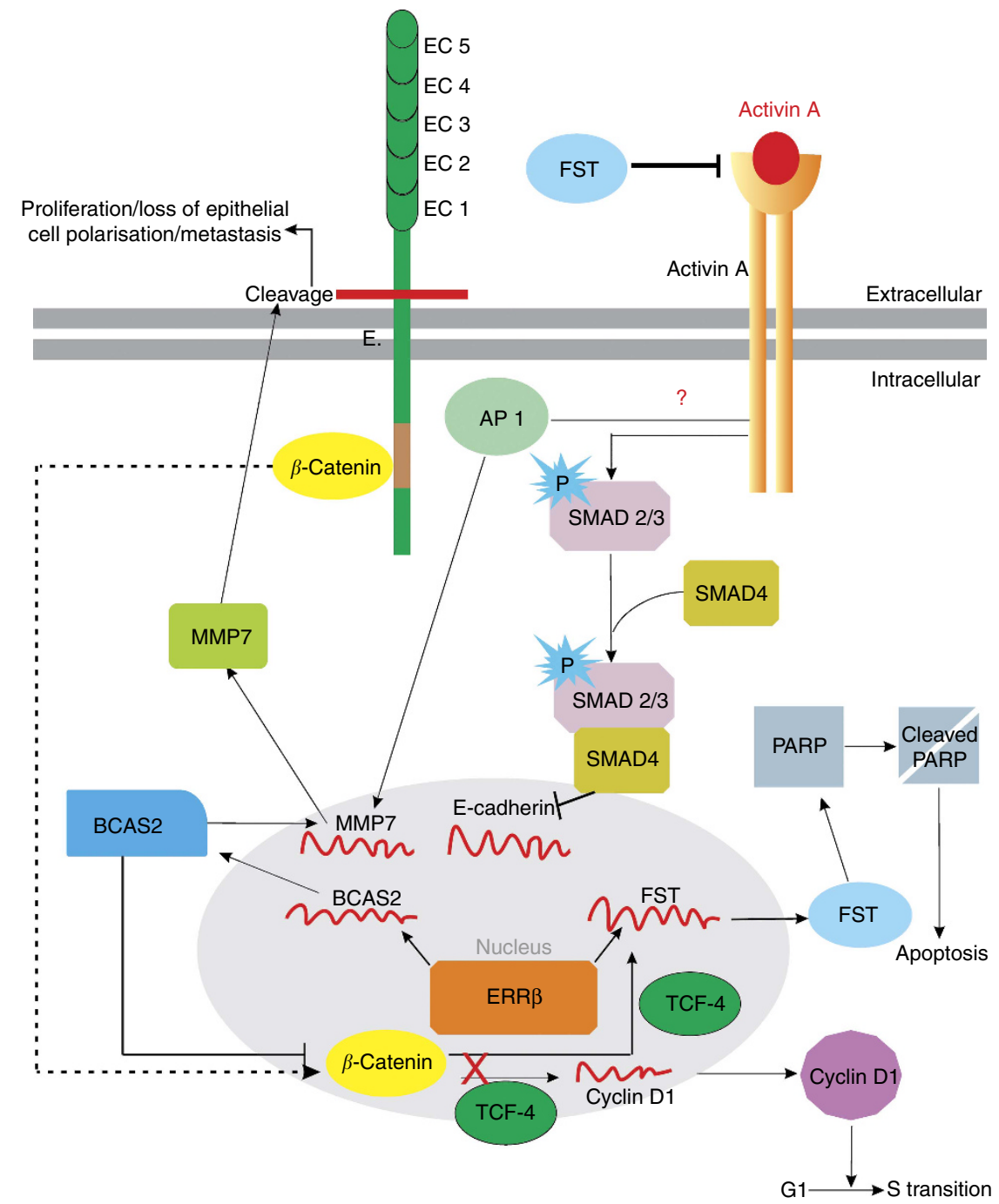

Figure 10. Diagrammatic representation showing different signalling pathways affected by ERR $\beta$ regulation through BCAS2 and FST. 
as an indicator of the blockade of EMT transition, which is a primary event for metastasis (Benton et al, 2009). We strongly believe that the identification of molecules that create fluctuations in natural $\operatorname{ERR} \beta$ activities should be pursued further. Future studies may identify more important transcriptional targets of $\operatorname{ERR} \beta$, which will provide in-depth knowledge of the functional significance of this molecule. Furthermore, more interacting partners and downstream targets of BCAS2 need to be identified to decipher the consequences of its amplification in breast cancer. Remarkably, FST is a candidate gene (Bhasin and Jasuja, 2009) for the development of selective androgen receptor modulators. New clinical trials of gene therapy using the overexpression of $\operatorname{ERR} \beta$ and the simultaneous inhibition of MMP7 in metastatic breast cancer need to be conducted considering their capacity to induce apoptosis and inhibit G1-S transition, EMT and multi-organ metastasis of human breast cancer cells selectively.

\section{ACKNOWLEDGEMENTS}

We are extremely grateful to our Director Professor B Ravindran for his support in the performance of this project. This research was financially supported by the Department of Science and Technology, Department of Biotechnology and University Grants Commission, Government of India. We express our gratitude to Dr Philippa Saunders, Director, MRC Centre for Reproductive Health, The Queen's Medical Research Institute, Edinburgh, for providing ER $\alpha$-CFP and ERR $\beta$-YFP constructs and Professor Kunihiro Tsuchida, Institute of Comprehensive Medical Sciences, Fujita Health University, Toyoake aichi, Japan for providing FSTpCDNA3.1 HA. We acknowledge Professor Ratna Vadlamudi, School of Medicine, UTHSCSA for the BCAS2 cDNA clone as a gift, Ms Rosalima Peter, Ms Kanchan Kumari and Mr Shashi Bhushan Sahoo for their support in the performance of several experiments and Mr Sanjib Chaudhary for providing tamoxifenresistant MCF-7 cells. We also thank Dr Satish Devadas, Senior Scientist, Institute of Life Sciences, for his guidance in flow cytometric analyses. Approval for the use of tumour samples was received from the Human Ethical Committee. Written informed consent for the use of tissue samples for research purposes was obtained from all patients.

\section{CONFLICT OF INTEREST}

The authors declare no conflict of interest.

\section{DISCLAIMER}

This is to certify that this work is not currently under consideration elsewhere, and all authors have seen and approved the submission of the manuscript for consideration for publication in the British Journal of Cancer.

\section{REFERENCES}

Ariazi EA, Clark GM, Mertz JE (2002) Estrogen-related receptor alpha and estrogen-related receptor gamma associate with unfavorable and favorable biomarkers, respectively, in human breast cancer. Cancer Res 62: 6510-6518.

Benton G, Crooke E, George J (2009) Laminin-1 induces E-cadherin expression in 3-dimensional cultured breast cancer cells by inhibiting DNA methyltransferase 1 and reversing promoter methylation status. FASEB J 23: 3884-3895.
Bhasin S, Jasuja R (2009) Selective androgen receptor modulators as function promoting therapies. Curr Opin Clin Nutr Metab Care 12: 232-240.

Bombail V, Collins F, Brown P, Saunders PT (2010) Modulation of ER alpha transcriptional activity by the orphan nuclear receptor ERR beta and evidence for differential effects of long- and short-form splice variants. Mol Cell Endocrinol 314: 53-61.

Boyle P, Levin B (2008) World Cancer Report. International Agency for Research on Cancer, ISBN 9789283204237.

Chen YG, Wang Q, Lin SL, Chang CD, Chuang J, YIng SY (2006) Activin signaling and its role in regulation of cell proliferation, apoptosis, and carcinogenesis. Exp Biol Med (Maywood) 231: 534-544.

David JM, Rajasekaran AK (2012) Dishonorable discharge: the oncogenic roles of cleaved E-cadherin fragments. Cancer Res 72: 2917-2923.

de Leeuw R, Neefjes J, Michalides R (2011) A role for estrogen receptor phosphorylation in the resistance to tamoxifen. Int J Breast Cancer 2011: 232435.

Dini L, Coppola S, Ruzittu MT, Ghibelli L (1996) Multiple pathways for apoptotic nuclear fragmentation. Exp Cell Res 223: 340-347.

Geyer FC, Rodrigues DN, Weigelt B, Reis-Filho JS (2012) Molecular classification of estrogen receptor-positive/luminal breast cancers. Adv Anat Pathol 19: 39-53.

Gyorffy B, Lanczky A, Eklund AC, Denkert C, Budczies J, Li Q, Szallasi Z (2010) An online survival analysis tool to rapidly assess the effect of 22,277 genes on breast cancer prognosis using microarray data of 1,809 patients. Breast Cancer Res Treat 123: 725-731.

Horard B, Castet A, Bardet PL, Laudet V, Cavailles V, Vanacker JM (2004) Dimerization is required for transactivation by estrogen-receptor-related (ERR) orphan receptors: evidence from amphioxus ERR. J Mol Endocrinol 33: 493-509.

Horard B, Vanacker JM (2003) Estrogen receptor-related receptors: orphan receptors desperately seeking a ligand. J Mol Endocrinol 31: 349-357.

Ito K, Okamoto I, Araki N, Kawano Y, Nakao M, Fujiyama S, Tomita K, Mimori T, Saya H (1999) Calcium influx triggers the sequential proteolysis of extracellular and cytoplasmic domains of E-cadherin, leading to loss of beta-catenin from cell-cell contacts. Oncogene 18: 7080-7090.

Janicke RU (2009) MCF-7 breast carcinoma cells do not express caspase-3. Breast Cancer Res Treat 117: 219-221.

Krneta J, Kroll J, Alves F, Prahst C, Sananbenesi F, Dullin C, Kimmina S, Phillips DJ, Augustin HG (2006) Dissociation of angiogenesis and tumorigenesis in follistatin- and activin-expressing tumors. Cancer Res 66: 5686-5695.

Kuo PC, Tsao YP, Chang HW, Chen PH, Huang CW, Lin ST, Weng YT, Tsai TC, Shieh SY, Chen SL (2009) Breast cancer amplified sequence 2, a novel negative regulator of the p53 tumor suppressor. Cancer Res 69: 8877-8885.

Li Y, Yuan YY, Meeran SM, Tollefsbol TO (2010) Synergistic epigenetic reactivation of estrogen receptor-alpha (ERalpha) by combined green tea polyphenol and histone deacetylase inhibitor in ERalpha-negative breast cancer cells. Mol Cancer 9: 274.

Lim SC, Lee MS (2002) Significance of E-cadherin/beta-catenin complex and cyclin D1 in breast cancer. Oncol Rep 9: 915-928.

Lin SY, Xia W, Wang JC, Kwong KY, Spohn B, Wen Y, Pestell RG, Hung MC (2000) Beta-catenin, a novel prognostic marker for breast cancer: its roles in cyclin D1 expression and cancer progression. Proc Natl Acad Sci USA 97: 4262-4266.

Lu D, Kiriyama Y, Lee KY, Giguère V (2001) Transcriptional regulation of the estrogen-inducible pS2 breast cancer marker gene by the ERR family of orphan nuclear receptors. Cancer Res 61: 6755-6761.

Lynch CC, Vargo-Gogola T, Matrisian LM, Fingleton B (2010) Cleavage of E-cadherin by matrix metalloproteinase-7 promotes cellular proliferation in nontransformed cell lines via activation of RhoA. J Oncol 2010: 530745.

Maass N, Rosel F, Schem C, Hitomi J, Jonat W, Nagasaki K (2002) Amplification of the BCAS2 gene at chromosome 1p13.3-21 in human primary breast cancer. Cancer Lett 185: 219-223.

Mintseris J, Pierce B, Wiehe K, Anderson R, Chen R, Weng Z (2007) Integrating statistical pair potentials into protein complex prediction. Proteins 69: 511-520.

Mishra SK, Mandal M, Mazumdar A, Kumar R (2001) Dynamic chromatin remodeling on the HER2 promoter in human breast cancer cells. FEBS Lett 507: 88-94.

Mukherjee S, Conrad SE (2005) c-Myc suppresses p21WAF1/CIP1 expression during estrogen signaling and antiestrogen resistance in human breast cancer cells. J Biol Chem 280: 17617-17625. 
Nilsson S, Makela S, Treuter E, Tujague M, Thomsen J, Andersson G, Enmark E, Pettersson K, Warner M, Gustafsson JA (2001) Mechanisms of estrogen action. Physiol Rev 81: 1535-1565.

Onder TT, Gupta PB, Mani SA, Yang J, Lander ES, Weinberg RA (2008) Loss of E-cadherin promotes metastasis via multiple downstream transcriptional pathways. Cancer Res 68: 3645-3654.

Pierce BG, Hourai Y, Weng Z (2011) Accelerating protein docking in ZDOCK using an advanced 3D convolution library. PLoS One 6: e24657.

Pontes Jr J, Srougi M, Borra PM, Dall' Oglio MF, Ribeiro-Filho LA, Leite KR (2010) E-cadherin and beta-catenin loss of expression related to bone metastasis in prostate cancer. Appl Immunohistochem Mol Morphol 18: 179-184.

Qi C, Zhu YT, Chang J, Yeldandi AV, Rao MS, Zhu YJ (2005) Potentiation of estrogen receptor transcriptional activity by breast cancer amplified sequence 2. Biochem Biophys Res Commun 328: 393-398.

Resnitzky D, Gossen M, Bujard H, Reed SI (1994) Acceleration of the G1/S phase transition by expression of cyclins D1 and $\mathrm{E}$ with an inducible system. Mol Cell Biol 14: 1669-1679.

Riggins RB, Lan JP, Zhu Y, Klimach U, Zwart A, Cavalli LR, Haddad BR, Chen L, Gong T, Xuan J, Ethier SP, Clarke R (2008) ERRgamma mediates tamoxifen resistance in novel models of invasive lobular breast cancer. Cancer Res 68: 8908-8917.

Riggins RB, Mazzotta MM, Maniya OZ, Clarke R (2010) Orphan nuclear receptors in breast cancer pathogenesis and therapeutic response. Endocr Relat Cancer 17: R213-R231.

Roy A, Kucukural A, Zhang Y (2010) I-TASSER: a unified platform for automated protein structure and function prediction. Nat Protoc 5: $725-738$.

Singh R, Bhasin S, Braga M, Artaza JN, Pervin S, Taylor WE, Krishnan V, Sinha SK, Rajavashisth TB, Jasuja R (2009) Regulation of myogenic differentiation by androgens: cross talk between androgen receptor/ beta-catenin and follistatin/transforming growth factor-beta signaling pathways. Endocrinology 150: 1259-1268.

Steinhusen U, Weiske J, Badock V, Tauber R, Bommert K, Huber O (2001) Cleavage and shedding of E-cadherin after induction of apoptosis. J Biol Chem 276: 4972-4980.

Talmadge JE (2008) Follistatin as an inhibitor of experimental metastasis. Clin Cancer Res 14: 624-626.

Tremblay GB, Kunath T, Bergeron D, Lapointe L, Champigny C, Bader JA, Rossant J, Giguere V (2001) Diethylstilbestrol regulates trophoblast stem cell differentiation as a ligand of orphan nuclear receptor ERR beta. Genes Dev 15: 833-838.
Vanacker JM, Pettersson K, Gustafsson JA, Laudet V (1999) Transcriptional targets shared by estrogen receptor- related receptors (ERRs) and estrogen receptor (ER) alpha, but not by ERbeta. EMBO J 18: 4270-4279.

Vincent T, Neve EP, Johnson JR, Kukalev A, Rojo F, Albanell J, Pietras K, Virtanen I, Philipson L, Leopold PL, Crystal RG, De Herreros AG, Moustakas A, Pettersson RF, Fuxe J (2009) A SNAIL1-SMAD3/4 transcriptional repressor complex promotes TGF-beta mediated epithelial-mesenchymal transition. Nat Cell Biol 11: 943-950.

Wade CB, Robinson S, Shapiro RA, Dorsa DM (2001) Estrogen receptor (ER)alpha and ERbeta exhibit unique pharmacologic properties when coupled to activation of the mitogen-activated protein kinase pathway. Endocrinology 142: 2336-2342.

Wang F, Reierstad S, Fishman DA (2006) Matrilysin over-expression in MCF-7 cells enhances cellular invasiveness and pro-gelatinase activation. Cancer Lett 236: 292-301.

Wong AS, Gumbiner BM (2003) Adhesion-independent mechanism for suppression of tumor cell invasion by E-cadherin. J Cell Biol 161: 1191-1203.

Xiong Y, Hannon GJ, Zhang H, Casso D, Kobayashi R, Beach D (1993) p21 is a universal inhibitor of cyclin kinases. Nature 366: 701-704.

Yoshinaga K, Mimori K, Inoue H, Kamohara Y, Yamashita K, Tanaka F, Mori M (2008) Activin A enhances MMP-7 activity via the transcription factor AP-1 in an esophageal squamous cell carcinoma cell line. Int J Oncol 33: 453-459.

Yu S, Wong YC, Wang XH, Ling MT, Ng CF, Chen S, Chan FL (2008) Orphan nuclear receptor estrogen-related receptor-beta suppresses in vitro and in vivo growth of prostate cancer cells via p21(WAF1/CIP1) induction and as a potential therapeutic target in prostate cancer. Oncogene 27: 3313-3328.

Zhou W, Liu Z, Wu J, Liu JH, Hyder SM, Antoniou E, Lubahn DB (2006) Identification and characterization of two novel splicing isoforms of human estrogen-related receptor beta. J Clin Endocrinol Metab 91: 569-579.

(c) (1) (2) (2) This work is licensed under the Creative Commons (c) License. To view a copy of this license, visit http://creativecommons. org/licenses/by-nc-sa/3.0/

Supplementary Information accompanies this paper on British Journal of Cancer website (http://www.nature.com/bjc) 